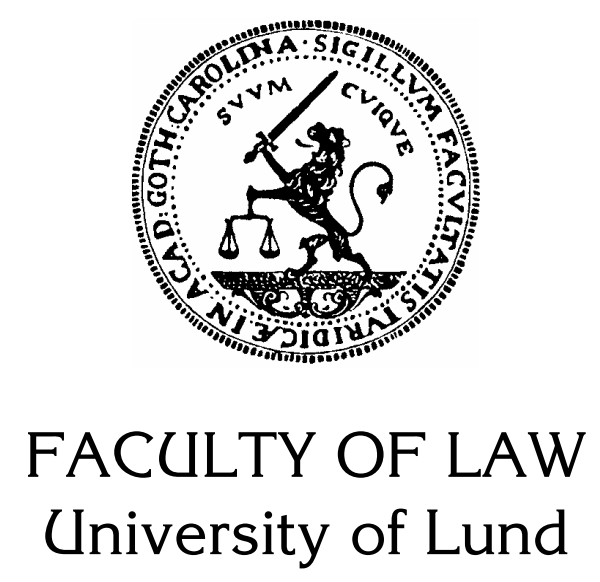

Master of International Human Rights Law Programme

\author{
Author: \\ Vincents Okechukwu Benjamin
}

What is the Role of Professional

and Civil Society Organisations

Beyond International Legal

Mechanisms of Implementing

Human Rights Treaties?

Master thesis

20 points

Supervisor:

Professor Ineta Ziemele

Public International Law

Autumn 2004 


\section{Contents}

WHAT IS THE ROLE OF PROFESSIONAL AND CIVIL SOCIETY ORGANISATIONS BEYOND INTERNATIONAL LEGAL MECHANISMS OF IMPLEMENTING HUMAN RIGHTS TREATIES?

1 INTRODUCTION 6

1.1 PURPOSE OF THE RESEARCH 6

1.2 OPERATIVE TERMS

1.2.1 Implementation: 6

1.2.2 Civil Society: $\quad 7$

$\begin{array}{lll}\text { 1.2.3 Professional Organisations: } & 7\end{array}$

1.3 METHOD AND MATERIAL 7

1.4 DELIMITATION 8

2 THE CHALLENGES OF IMPLEMENTING INTERNATIONAL HUMAN RIGHTS TREATIES - BACKGROUND 9

2.1 IMPLEMENTATION: INTERNATIONAL 10

2.2 THE CHALLENGE 11

2.2.1 Low-Level of Domestic Implementation? 12

2.2.2 The Paradox of Domestic Implementation of International Law in the Sphere of Human Rights 15

2.3 THE LIMITATIONS THAT NECESSITATE THE QUEST FOR ALTERNATIVE WAYS TO IMPLEMENT THE TREATIES

2.3.1 Independence/Sovereignty of States 17

2.3.2 Lack of Incentive for Inter-State Complaints 19

2.3.3 Incorporation of Human Rights Treaties 19

2.4 MEETING THE CHALLENGE 20

3 THE LEGAL BASIS IN INTERNATIONAL LAW FOR PROFESSIONAL AND CIVIL SOCIETY ORGANISATIONS PARTICIPATION

3.1 THE CHARTER PROVISIONS 23

3.2 THE UN DECLARATIONS AND RESOLUTIONS 24

3.2.1 Declaration on the Right and Responsibility of Individuals, Groups and Organs of Society to Promote and Protect Universally Recognized Human Rights and Fundamental Freedoms

3.2.2 Basic Principles on the Role of Lawyers 27

3.2.3 The Vienna Declaration and Programme of Action 27 
3.2.4 The Universal Declaration of Human Rights and the Vienna Declaration and Programme of Action on Human rights Education

3.2.5 The VDPA and the Resolution on UN Technical Assistance/Cooperation and Advisory Services

3.3 HUMAN RIGHTS TREATIES PROVISIONS AND INTERPRETATION BY TREATY BODIES GENERAL COMMENTS

3.3.1 The International Covenant on Economic Social and Cultural Rights and Education

3.3.2 The International Covenant on Civil and Political Rights

3.4 ARE THERE OBLIGATIONS ON PROFESSIONAL AND CIVIL SOCIETY ORGANISATIONS TO PLAY THE ROLE?

3.5 ILLUSTRATIONS FROM DECIDED CASES

4 HUMAN RIGHTS EDUCATION/ENLIGHTENEMENT AND THE ROLE OF PROFESSIONAL ORGANISATIONS

4.1 HUMAN RIGHTS EDUCATION GENERAL

4.2 PROFESSIONAL ORGANISATIONS AT PRIMARY AND SECONDARY EDUCATION LEVELS

4.2.1 Potential for Human Rights Promotion 42

4.2.2 Current Achievements 44

4.3 PROFESSIONAL ORGANISATIONS AT TERTIARY EDUCATION LEVEL

4.3.1 The Role of the Professional Associations and Regulatory Organisations

4.3.2 The Role of Lecturers Unions

4.3.3 Who Will Teach The Teachers? 49

$\begin{array}{ll}4.4 & 50 G A L\end{array}$

4.4.1 The Role of Professional Organisations in Legal Education 50

5 CIVIL SOCIETYINON-GOVERNMENTAL ORGANISATIONS PARTICIPATION 53

5.1 TRIBUTE TO CIVIL SOCIETY ORGANISATIONS 53

5.2 SELECTED HIGHLIGHTS ON THE ROLE OF NGOS 54

5.2.1 Participation in the Political Process 55

5.2.2 Litigation, Public Interest Litigation and other Legal Processes 55

5.2.3 Public Education and Information Provision 58

5.2.4 Human Rights Training For Judges 59

5.2.5 Research and Generation of Policy Alternatives 60

6 REALISATION OF THE ROLE-CONCLUSION 61

6.1 OBSTACLES TO THE PERFORMANCE OF PROFESSIONAL AND CIVIL SOCIETY ORGANISATIONS 
6.1.1 Professional Organisations 61

6.1.2 Civil Society Organisations $\quad 62$

6.2 UN TECHNICAL COOPERATION PROGRAMME 63

6.2.1 Content of the Programme 63

6.2.2 At the Request of States! 66

6.3 CREATING CIVIL SOCIETY 68

6.3.1 Rethinking Technical Cooperation Programmes 69

6.4 CONCLUDING REMARKS 70 


\section{Summary}

The thesis is divided into six chapters. Chapter 1 is the introduction while chapter 2 really starts the discourse. Chapter 2 is titled, the Challenges of Implementing International Human Rights Treaties-Background, it outlines the international mechanisms of implementation envisaged by the treaties and indicates that the treaties originate at the international plane but are designed for implementation at both the international and domestic planes, the domestic being the envisaged primary level of implementation. It then sought to establish that implementation at the domestic level is froth with very many challenges and that low-level of implementation is evident in many jurisdictions. Further discussions in this chapter reveal that much as it is desirable that international mechanisms reach into the various domestic systems and instigate implementation, international mechanisms are limited in this regard by independence and sovereignty of states; lack of incentive for inter-state complaints; and non-incorporation of the treaties into domestic jurisdictions. The chapter concludes by suggesting professional and civil society organisations as viable alternative agents of implementation.

Chapter 3 is on the international law basis for the participation of the organisations. Starting from UN Charter provisions, to UN Declarations/Resolutions and down to treaty provisions as interpreted by treaty monitoring bodies, the chapter reveals a clear call for all persons, including groups and institutions to promote and defend human rights and suggests a duty to the same end including through education and dissemination of relevant information. Professional and civil society organisations are lucidly included in this call. The chapter concludes by inquiring into whether there is indeed an obligation on professional and civil society organisations to participate by answering the call embodied in the examined instruments particularly regarding human rights education.

Chapter 4 is on the role of professional organisations in human rights education. Three levels of education are discussed, primary/secondary, tertiary and legal education. The organisations identified as having the potentials to contribute to treaty implementation through education include the various teachers union at the primary/ secondary level, Lecturers union and regulatory bodies as well as trade unions and associations of the different professions that contribute to the education delivery system. For legal education, law teachers associations were identified as well as the different bar associations and law societies. The underlying consideration in the chapter is that these organisations are capable of contributing to the building of a positive human rights culture that will in turn facilitate treaty implementation; after all, the students of today are the policy makers, judges and legislators of tomorrow. 
Chapter 5 pays tribute to NGOs and highlights participation in the political process, leading to treaty implementation; litigation and other legal processes; public education; research and generation of policy alternatives as well as training for judges as examples of the very important roles that civil society organisations can play towards treaty implementation efforts.

Chapter 6 is the conclusion and it discusses some problems inherent in the identified roles and in the operation of professional and civil society organisations. It emphasises the UN Technical Cooperation Programme in the Field of Human Rights as an example of available solutions and issues a few words of concern on the running of technical cooperation programmes, which if ameliorated, would enhance the role of professional and civil society organisation. 


\section{Preface}

This thesis is born out of a seething desire to contribute to the advancement of human rights. On the realisation that as at 1996, when I graduated from the University of Nigeria, all the six major UN human rights treaties had entered into force and their various implementation mechanisms were in full swing yet I had no detailed instructions on them, I saw then that more needs to be done. A little research reveals that the trend of graduating lawyers with no knowledge of international human rights law continues in many other schools and countries. Aside from lawyers, many other professionals are in the same boat. My conviction then is that novel approaches need to be researched if there would be hopes of a more wholesome human rights culture around the world. I have accordingly identified professional and civil society organisations as alternatives worth some attention.

On researching this topic, the giant strides of the human rights movement became pronounced and I would have liked to take comfort in the very many achievements. However, having lived in more than one developing country where many institutionalised practices violate basic human rights and seeing nations who can arguably claim to have perfected respect for civil liberties struggle with refugee rights and racial discrimination, I can only posit that we have not yet reached the comfort zone.

In the light of the universality, interrelatedness and indivisibility of human rights, the struggle can only continue for implementation in developed and developing nations alike. One of the important contributions of this thesis is that it delves into the domestic realm to identify some key players in the working of the society with the capability to influence implementation. International law texts are not lacking in detailing the international legal mechanisms of implementation as in monitoring, reporting, individual complaints procedures etc. Nevertheless, there seems to be a dearth of analysis on the domestic players. Importantly the professional and civil society organisations identified in this thesis are actually susceptible to international influence via affiliations to international federations of such organisations. Hence, once the will to implement increases on the part of more states, greater support and resources can be given to these organisations and this in my view would take us one step closer to global respect for human rights. Primary responsibility for human rights treaties implementation continues to rest on state parties 


\section{Abbreviations}

\begin{tabular}{|c|c|}
\hline AEU & Australian Education Union \\
\hline CAT & $\begin{array}{l}\text { Convention Against Torture and Other Cruel, } \\
\text { Inhuman or Degrading Treatment or Punishment }\end{array}$ \\
\hline CEDAW & $\begin{array}{l}\text { Convention on the Elimination of All Forms of } \\
\text { Discrimination Against Women }\end{array}$ \\
\hline CERD & $\begin{array}{l}\text { Convention on the Elimination of all Forms of } \\
\text { Racial Discrimination }\end{array}$ \\
\hline CESCR & $\begin{array}{l}\text { Covenant on Economic Social and Cultural } \\
\text { Rights }\end{array}$ \\
\hline CRC & Convention on the Rights of the Child \\
\hline ECHR & European Convention on Human Rights \\
\hline EI & Education International \\
\hline GA & General Assembly \\
\hline HRC & Human Rights Committee \\
\hline HREOC & $\begin{array}{l}\text { Human Rights and Equal Opportunities } \\
\text { Commission (Australia) }\end{array}$ \\
\hline ICCPR & $\begin{array}{l}\text { International Covenant on Civil and Political } \\
\text { Rights }\end{array}$ \\
\hline ICJ & International Court of Justice \\
\hline IHL & International Humanitarian Law \\
\hline NGO & Non-Governmental Organisations \\
\hline NMA & Nigerian Medical Association \\
\hline NUT & National Union of Teachers \\
\hline $\mathrm{OHCHR}$ & $\begin{array}{l}\text { Office of the High Commissioner for Human } \\
\text { Rights }\end{array}$ \\
\hline PIL & Public Interest Litigation \\
\hline
\end{tabular}


UDHR

UN

VDPA

WHO
Universal Declaration on Human Rights

United Nations

Vienna Declaration and Plan of Action

World Health Organisation 


\section{Introduction}

Standard setting in the field of human rights has come of age. From universal instruments down to regional instruments and then national legislations, states and intergovernmental organisations have largely succeeded in making provisions that have identified and established very many individual rights. The current challenge is to ensure that these rights are realised in the lives of the people for whom they were designed. To this end, many governments have gone a long way in giving effect to the rights they contracted to preserve for their people and have worked hand in glove with the monitoring mechanisms established by some of the instruments. States are however at different levels of commitment to giving effect to the obligations in those instruments and sadly, some states are very backward in this respect. Accordingly, there seems to be a consensus that the most pressing challenge in this field is that of implementation. In discussing this implementation challenge, I have chosen to limit my analysis to the six major UN adopted human rights treaties.

\subsection{PURPOSE OF THE RESEARCH}

The basic assumption of the thesis is that professional and civil society organisations are suited to contribute solutions to the implementation problem. This assumption is fuelled by the fact that these organisations are located within the jurisdiction of states and they are consequently not hampered by the factors that limit the reach of international mechanisms into the domestic sphere to instigate implementation. Additionally, the very structures of these organisations reveal potentials for the role. The purpose of the thesis is therefore primarily to identify the different types of bodies that constitute professional and civil society organisations and indicate the nature of activities they carry out or could carry out to facilitate implementation in their countries. As a backdrop, the thesis would seek to touch on the said factors that limit the reach of international mechanisms into national jurisdictions and seek to establish the international law basis for the participation of professional and civil society organisation. By way of conclusion, the thesis would touch on some factors that could aid the organisations in realising the identified role, the UN Technical Cooperation Programme in the Field of Human Rights would be emphasised.

\subsection{OPERATIVE TERMS}

\subsubsection{Implementation:}

To implement means "to put a plan or system into operation," the term refers to the process of ensuring that the rights established by the treaties are 
entrenched in the legal system of the country by legislative, judicial or administrative practice. Implementation is proactive since it empowers the people when their rights and freedoms are guaranteed in the legal system. A closely related word is 'enforcement', which refers to practical application of the treaties. To enforce means to "make people obey the law or to make a particular situation happen or be accepted"ii enforcement is reactive. A close look reveals that implementation and enforcement sometimes overlap, particularly in the human rights field. Consequently, in this thesis, the term 'implementation' is assigned the meaning "to give effect to treaty obligations" in line with the language of the treaties in focus ${ }^{\mathrm{iii}}$ it encompasses the adopting of measures to make the treaties operational in each jurisdiction as well as provision of redress or effective remedy whenever recognised rights are violated ${ }^{\text {iv }}$

\subsubsection{Civil Society:}

The term has been defined as "a sphere of social interaction between economy and state, composed above all of the intimate (especially the family), the sphere of associations (especially voluntary associations), social movements, and forms of public communication."v Civil society is hence often categorised as a third sector placed between the state and market economy to which much of the development of democratic society is attributed. $^{\text {vi }}$ Non- Governmental organisations would be used as representatives of civil society in this thesis.

\subsubsection{Professional Organisations:}

This term refers to organised groups of people of the same profession. 'Profession' means "any type of work, which needs special training or a particular skill, often one which is respected because it involves a high level of education."vii

\subsection{METHOD AND MATERIAL}

I initiated the research by conducting discussions with lawyers and NGO operators from different countries to verify that there is indeed a possible role for professional and civil society organisations. These lawyers were drawn from LL.M students (2003) at the Raoul Wallenberg Institute of Human Rights and Humanitarian law. These discussions gave me interesting insight into the workings of the human rights systems in various countries including Tanzania, Uganda, Ireland, Sweden, Malawi and Brazil. I also drew from my experience in legal practice in Nigeria and participation in civil society activities in Cameroon. 
I thereafter surveyed my topic by use of textbooks and by reading up relevant articles mostly from Internet sources. On the identified professional and civil society organisations, I relied on information on the websites of the different organisations to verify my ideas and the final positions I took, where the websites did not have sufficient information, I supplemented by making inquiries by email.

For the texts of treaties and other international instruments, I used The Raoul Wallenberg Institute Compilation of Human Rights Instruments and supplemented with the database maintained by the Office of the UN High Commissioner for Human Rights, the later also provided me with information on the concluding observations and general comments of the treaty monitoring bodies in focus. For the few ICJ cases, I made use of the law reports at the RWI library and supplemented with the databases of Westlaw International. I also partially relied on Westlaw International for the cases of the different jurisdictions discussed.

For factual information on domestic implementation, I relied on the research results published in Christof Heyns and Frans Viljoen's The Impact of the United Nations Human Rights Treaties on the Domestic Level. ${ }^{\text {viii }}$ In addition, for the litigation and other roles of civil society I placed partial reliance on the report on the WHO Tobacco Free Initiative "Consultation on litigation and Public Inquiries as Public Health Tools", held in 2001 at Amman, Jordan. The report is published in D. Blanke's 'Towards Health with Justice Litigations and Public Inquiries as Tools of Tobacco Control. ${ }^{\text {ix }}$

\subsection{DELIMITATION}

To conserve research effort and enhance focus, I chose to limit analysis to the six major UN-adopted human rights treaties. The International Convention on the Elimination of all Forms of Racial Discrimination (CERD) (1965); the International Covenant on Economic, Social and Cultural Rights (CESCR) (1966); the International Covenant on Civil and Political Rights (ICCPR) (1966) and its first Optional Protocol (OP1); the Convention on the Elimination of All Forms of Discrimination Against Women (CEDAW) (1979); the Convention Against Torture and Other Cruel, Inhuman or Degrading Treatment or Punishment (CAT) (1984); and the Convention on the Rights of the Child (CRC) (1989). Consequently regional treaties and mechanisms are only in the periphery of the thesis and are considered only in passing notwithstanding that the identified roles apply equally to them. In the same vain, related topics like national institutions, the role of the media as well as details on international implementation mechanisms are deliberately not dealt with. The thesis focuses on implementation at the domestic level and discusses only two classes of players: professional and civil society organisation. 


\section{THE CHALLENGES OF IMPLEMENTING INTERNATIONAL HUMAN RIGHTS TREATIES - BACKGROUND}

International law authors approach the historical development of international human rights law from various perspectives ${ }^{1}$ but consensus seems to converge around the atrocities of the Second World War as providing the immediate backdrop for the contemporary treaty regime on the subject. “...nazi expansion and extermination practices under Hitler, coinciding with Stalin's reign of terror in the Soviet Union. These developments laid the groundwork for a broad consensus that a new humanistic legal order would be established." ${ }^{2}$ This broad consensus found its first detailed expression in the adoption of the Universal Declaration of Human Rights (UDHR) on the $10^{\text {th }}$ of December1948. Since the UDHR, the international community has embarked on a vigorous process of standard setting in the sphere of human rights. This has resulted in many treaties being adopted, including the six United Nations treaties that are particularly in focus in this thesis. The International Convention on the Elimination of all Forms of Racial Discrimination (CERD) (1965); the International Covenant on Economic, Social and Cultural Rights (CESCR) (1966); the International Covenant on Civil and Political Rights (ICCPR) (1966) and its first Optional Protocol (OP1); the Convention on the Elimination of All Forms of Discrimination Against Women (CEDAW) (1979); the Convention Against Torture and Other Cruel, Inhuman or Degrading Treatment or Punishment (CAT) (1984); and the Convention on the Rights of the Child (CRC) (1989). ${ }^{3}$

\footnotetext{
${ }^{1}$ See M. N. Shaw International Law (Cambridge University Press, Cambridge, 2003) pp.252-253; L. Henkin 'International Law: Politics, Values and Functions', in H. Steiner and P. Alston International Human Rights in Context (Oxford University Press, Oxford, 2000) pp. 127-130; A. Eide and G. Alfredsson 'Introduction', in G. Alfredsson and A. Eide (eds.) The Universal Declaration of Human Rights (Kluwer Law International, The Hague, 1999) pp. Xxv-Xxviii.

${ }^{2}$ Ibid. p. xxvii.

${ }^{3}$ See generally C. Heyns and F. Viljoen 'The Impact of the United Nations Human Rights Treaties on the Domestic Level', 23 Human Rights Quarterly (2001) p. 484

$<$ muse.jhu.edu/journals/human_rights_quarterly/v023/23.3heyns.html>, visited on 30 June 2004.
} 


\subsection{IMPLEMENTATION: INTERNATIONAL}

Each of these treaties has set up a specific body to monitor and enforce compliance with the treaty provisions. ${ }^{4}$ The system of monitoring and implementation generally employed by the treaty bodies can be summarised as follows:

REPORTING: includes the Initial Report and Periodic Reports and is considered the most important system of implementing and enforcing human rights available in the UN system. ${ }^{5}$ Indeed, "Periodic reporting is the most widespread and established implementation technique for the international implementation of human rights. ${ }^{6}$ Under this system, states are obliged to report to the relevant body on the measures taken to secure respect for the rights contained in the treaty. ${ }^{7}$ In considering the reports, the various treaty bodies usually utilise information from alternative sources such as non-governmental organisations, the press, or UN specialised agencies. This is important since reports can suffer from many inadequacies, they can be too brief, ambiguous or self-serving ${ }^{8}$

COMPLAINTS: “The complaints procedure is used as an enforcement mechanism by individuals and NGOs who allege that their rights have been violated by the State in whose jurisdiction they live or are subject to." ${ }^{99}$ It is generally a procedure for settling grievances in an essentially quasi-judicial manner. Depending on the treaty under consideration, the procedure is generally available to individuals, NGOs and States. ${ }^{10}$

STUDIES AND INVESTIGATIONS: this system is not limited to the treaty bodies but runs through the whole of UN human rights system. Experts in international human rights law and other relevant fields are authorised to carry out investigations, inquiries and studies of human rights violations either in any part of the world or in a specific country. This procedure encompasses the working groups and special rapporteurs appointed by the UN and the Inquiry Procedure under CEDAW ${ }^{11}$

\footnotetext{
${ }^{4}$ Committee on Elimination of all Forms of Racial Discrimination; Committee on Economic Social and Cultural Rights; Human Rights Committee; Committee on Elimination of Discrimination Against Women; Committee Against Torture and Committee on the Rights of the Child.

${ }^{5}$ See P. Matsheza and L. Zulu Human Rights Enforcement and Implementation

Mechanisms (Human Rights Trust of Southern Africa, Harare, 2001) p. 14

${ }^{6}$ D. McGoldrick The Human Rights Committee Its Role in the Development of the International Covenant on Civil and Political Rights (Oxford University Press, New York, 1994) p.62.

${ }^{7}$ See, Matsheza, Supra note 5.

${ }^{8}$ See, S. Joseph et al. The International Covenant on Civil and Political Rights Cases, Materials, and Commentary (Oxford University Press, New York, 2000) pp.11-12

${ }^{9}$ Matsheza, Supra, note 5

${ }^{10}$ Ibid

${ }^{11}$ See generally, Matsheza, Supra note 5.
} 


\title{
2.2 THE CHALLENGE
}

Today, standard setting for the protection of human rights has largely come to some maturity at the international plane and focus is shifting to implementation particularly at the national level. "The challenge now is to ensure that the promises contained in the treaties and affirmed through ratification are realised in the lives of ordinary people around the world. A paradigm shift to the true "customers" of the system is necessary. ${ }^{12}$ The enormity of the challenges of implementing and enforcing international human rights law does not become so apparent when one considers implementation only at the international level as in the mechanisms summarised above because the said mechanisms are up and running at the very least. The challenges become all too clear when the treaty regimes are put in proper perspective emphasising that the treaties were designed to be implemented at two levels: municipal and international. Moreover, the municipal is the envisaged primary level of implementation. Using the ICCPR as an example,

\begin{abstract}
"Though the ICCPR imposes duties upon states in the international plane of law, it is envisaged that the implementation of the rights therein is primarily a domestic matter...International enforcement measures such as the supervisory mechanisms of the HRC, are designed to be a secondary source of ICCPR rights protection.,"13
\end{abstract}

This is probably a correct interpretation of Article 2 of the ICCPR. ${ }^{14}$ In my view, despite the inherent inefficiencies of the international mechanisms (backlogs, overlaps, vagueness in findings and the routine disregard of findings by states when domestic convenience so dictates), ${ }^{15}$ the major challenges of implementing international human rights treaties are to be found elsewhere: domestic mechanisms. Part of the inefficiencies in the international mechanisms is a direct result of low-level implementation at the domestic sphere in some states. "A low level of domestic implementation of human rights norms in a particular country makes international supervision more important...in order for international human rights treaties to have an impact; an enabling domestic environment is required." ${ }^{16}$ Low-level domestic implementation therefore overburdens the international system. The domestic level then should be the centre of the

\footnotetext{
${ }^{12}$ Heyns, Supra note 3, pp.483-484.

${ }^{13}$ Joseph, Supra note 8, p. 9; See also A. Pennegård 'Article 5' in G. Alfredsson and A. Eide (eds.) The Universal Declaration of Human Rights (Kluwer Law International, The Hague, 1999) p. 122; Eric Mose 'Article 8' in G. Alfredsson and A. Eide (eds.) The Universal Declaration of Human Rights (Kluwer Law International, The Hague, 1999)pp. 187.

${ }^{14}$ See also Article 2 CESCR, Article 2 CERD, Article 2 CEDAW, Articles 2 and 4 CAT, Article 2 CRC

${ }^{15}$ See Heyns, supra note 3, p. 488

${ }^{16}$ Heyns, Supra note 3, p.518
} 
treaty implementation attention since "the realisation of human rights requires an effective implementation of the rights at the domestic level not only in law but also in fact." ${ }^{17}$.

\title{
2.2.1 Low-Level of Domestic Implementation?
}

The question then is whether there is indeed generally a low level of domestic implementation of human rights. The starting point to any inquiry into implementation is the provision in all the six international human rights treaties under consideration that:

\begin{abstract}
"Each State Party to the present Covenant undertakes to respect and to ensure to all individuals within its territory and subject to its jurisdiction the rights recognized in the present Covenant, without distinction of any kind, such as race, colour, sex, language, religion, political or other opinion, national or social origin, property, birth or other status.
\end{abstract}

2. Where not already provided for by existing legislative or other measures, each State Party to the present Covenant undertakes to take the necessary steps, in accordance with its constitutional processes and with the provisions of the present Covenant, to adopt such laws or other measures as may be necessary to give effect to the rights recognized in the present Covenant."18

Low-level domestic implementation in some states is one of the assumptions of this thesis; consequently, I intend to verify that assumption by way of analysis. Firstly, the operative term in Article 2(2) above are the words 'give effect' and as indicated, it should be by way of legislation and other measures. Other measures would necessary include judicial recognition and implementation of the treaty rights as well as implementation by the executive arm of the state.

The task of verifying wholesome implementation by these three arms of the government in each state is not a very easy one since the traditional reports on state human rights practices are not always so clearly demarcated. Fortunately, however some scholarly efforts provide some insight. A study initiated in January 1999 in collaboration with the Office of the UN High Commissioner for Human Rights, and concluded in June 2000 is useful for this purpose. The findings of the study are published in Christof Heyns and Frans Viljoen's The Impact of the United Nations Human Rights Treaties on the Domestic Level. ${ }^{19}$ Twenty countries were surveyed, four from each of the

\footnotetext{
${ }^{17}$ Eric Mose 'Article 8' in G. Alfredsson and A. Eide (eds.) The Universal Declaration of Human Rights (Kluwer Law International, The Hague, 1999) pp. 187.

${ }^{18}$ Article 2 International Covenant on Civil and Political Rights, 16 December 1966; See also Article 2 CESCR, Article 2 CERD, Article 2 CEDAW, Articles 2 and 4 CAT, Article 2 CRC.

${ }^{19}$ (Kluwer Law International, The Hague, 2002) also available in C. Heyns and F. Viljoen 'The Impact of the United Nations Human Rights Treaties on the Domestic Level', 23 Human Rights Quarterly (2001) $<$ muse.jhu.edu/journals/human_rights_quarterly/v023/23.3heyns.html>, visited on 30 June 2004.
} 
five UN regions. ${ }^{20}$ But I have chosen to set forth excerpts for the first five of the twenty countries below based on the level of awareness of the major UN human rights treaties by the government (executive) and lawyers (including judges in some cases) and also legislative reforms and judicial decision:

Australia:

Government: Generally speaking, the level of awareness of the six human rights treaties throughout the Australian governments, both ministerial and bureaucratic levels, is not high, there are exceptions to the rule. ${ }^{21}$

Lawyers: The human Rights treaties play no part in the work of legal practitioners in Australia. Even amongst lawyers in private practice who undertake discrimination cases the focus is wholly on the relevant domestic legislation. A number of judges - exclusively in the superior court- are also conversant with the treaties and have demonstrated that they are receptive to arguments based on them ${ }^{22}$

Legislative Reform: All law reform bodies in Australia (federal, state and territory) refer to and analyse international human rights treaties where they are relevant to their particular inquiries. ${ }^{23}$

Brazil:

Government: The general level of awareness and commitment among officials of the state is still relatively low. ${ }^{24}$

Lawyers: The level of awareness of the core treaties is relatively low. However this scenario has gradually begun to change in recent years. Some attorneys and judges have started to apply international human rights norms in contentious litigation. ${ }^{25}$

Judicial Decisions: although treaties are rarely invoked in courts, some references were found in cases before the national courts. ${ }^{26}$

Canada:

Government: The general awareness of the treaties among government officials tend to be localised within those departments and jurisdictions with primary responsibility for preparing Canada's reports to the treaty bodies and those with mandates similar to the principles of the treaties. ${ }^{27}$

Lawyers: Generally, awareness by lawyers of the treaties is localised among those whose areas of expertise include human rights and international law. ${ }^{28}$

Legislative Reforms: Limited legislative reforms were made at the time of the ratification of the treaties. ${ }^{29}$

Judicial Decisions: Canadian courts do not rely heavily on human rights treaties as the basis of judicial decision-making; even the use of the treaties by the courts as interpretative guides is rare. ${ }^{30}$

Columbia:

Government: knowledge of the treaty system is confined largely to those who participate in the reporting process, who see their task as responding to the formal demands of the process. ${ }^{31}$

${ }^{20}$ Africa; Asia; Eastern Europe; Latin America and the Caribbean; and Western Europe.

${ }^{21}$ C. Heyns and F. Viljoen's The Impact of the United Nations Human Rights Treaties on the Domestic Level (Kluwer Law International, The Hague, 2002) p.56.

${ }^{22}$ Ibid, p.60

${ }^{23} \mathrm{Ibid}$, p.61

${ }^{24} \mathrm{Ibid}$, p.97

${ }^{25} \mathrm{Ibid}$, p. 100

${ }^{26}$ Ibid, p.103

${ }^{27}$ Ibid, p.119

${ }^{28} \mathrm{Ibid}, \mathrm{p} .122$

${ }^{29}$ Ibid, p.124

${ }^{30}$ Ibid, p.125

${ }^{31}$ Ibid, p.169 
Lawyers: only those lawyers - in government, private practice or NGOs with some exposure to the treaty system are familiar with it. ${ }^{32}$

Legislative Reform: There is very little indication of a conscious effort by the legislature to implement international human rights norms. ${ }^{33} \mathrm{P} .171$

Judicial Decisions: In sharp contrast to the legislature, parts of the judiciary - in particular the constitutional court - play a very active role in implementing the treaties by testing laws against the "block of constitutionality..."34

Czech Republic:

Government: the general level of awareness differs among the treaties as follows: CERD, high; CESCR, not very high; CCPR, relatively high; CEDAW, low; CAT, high; CRC, average. ${ }^{35}$

Lawyers: Although the new generation of lawyers is more exposed to the treaties, awareness remains limited aside from the members of the constitutional court. ${ }^{36}$

Legislative Reform: there is no legislation that directly refers to the treaties. However, the overriding principle of Czech policy is respect for human rights. ${ }^{37}$

Judicial Decisions: Court reference to international human rights treaties occur somewhat infrequently ${ }^{38}$.

From these excerpts, doubtlessly, the treaty system has had enormous influence at the domestic level. Government officials and the new generation of lawyers and judges are more aware of the treaties. Additionally, available evidence suggests that the treaties have contributed in shaping the present understanding of basic human rights all over the world.

This notwithstanding, wholesome implementation of the treaties is not yet reached in a good number of states, unfortunately, even the general best practice amongst the surveyed states shows some rooms for improvement. Common concerns would include where the awareness of the treaties is localised within the departments of the government charged with the duty of preparing reports for the international monitoring mechanisms. Instances where knowledge of the treaties is limited to the new generation of lawyers and those that deal specifically with human rights; limited legislative reform upon ratification of the treaties and infrequent references to the treaties in judicial decisions. In some other states, there are some more serious concerns like low level of awareness in the government, absence of the treaties in national litigations, little or no legislative reforms implementing the treaties and reluctance in the judiciary to employ the treaties even for interpretative purposes. For the latter states, the level of implementation of the treaties could be said to be low.

\footnotetext{
${ }^{32}$ Ibid, p. 170

${ }^{33}$ Ibid, p.171

${ }^{34}$ Ibid.

${ }^{35}$ Ibid, pp.203-204

${ }^{36}$ Ibid, p.207

${ }^{37}$ Ibid, p.208

${ }^{38}$ Ibid, p.210
} 
The concluding observations and comments by the Human Rights Committee on the latest reports on the implementation of the ICCPR by the five states excerpted above reveal traces of low level of domestic implementation in some of the states and areas of concern for the others. The conclusions range from a catalogue of widespread human rights violations in Colombia ${ }^{39}$ and Brazil. ${ }^{40}$ To lamenting the absence of a constitutional Bill of Rights in Australia ${ }^{41}$ and gaps between the protection of rights under the Canadian charter and other federal and provincial laws and the protection required under the Covenant. ${ }^{42}$ Beyond the foregoing, concluding observations and comments from all the treaty monitoring bodies and country reports on human rights ${ }^{43}$ contain reports of gross and continuous violations of human rights in some of the countries that have ratified the six human rights treaties under consideration. In varying degrees, depending on the country being considered, Low-level domestic implementation of the treaties therefore remains very much a challenge in the contemporary human rights field.

\subsubsection{The Paradox of Domestic Implementation of International Law in the Sphere of Human Rights}

In the preceding section, I endeavoured to show the level of domestic implementation of a body of laws that is international. This in itself is a paradox given that international law traditionally regulates the relationship between nations, imposes duties and obligations as well as guarantees rights in the international plane. Nevertheless, Domestic implementation remains the envisaged primary level of implementation of human rights treaties. The propriety of this multi level implementation and discussion of human rights law needs some explanation. It is indeed possible to study human rights and its implementation not at the international level but in the

39 See Concluding observations of the Human Rights Committee: Colombia, CCPR/CO/80/COL, 26/05/2004,

$<$ www.unhchr.ch/tbs/doc.nsf/(Symbol)/25801461ec26db5dc1256ead00300713?Opendocu

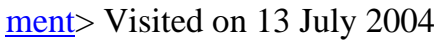

${ }^{40}$ See Concluding Observations of the Human Rights Committee: Brazil, CCPR/C/79/Add.66; A/51/40, 24/07/96, paras.306-338,

<www.unhchr.ch/tbs/doc.nsf/(Symbol)/9d8f4abc5536855fc12563ea0057e768?Opendocum ent $>$ Visited on 13 July 2004

${ }^{41}$ See Concluding observations of the Human Rights Committee: Australia, A/55/40, 24/07/2000, paras.498-528, <www.unhchr.ch/tbs/doc.nsf/(Symbol)/e1015b8a76fec400c125694900433654?Opendocum ent $>$ Visited on 13 July 2004

${ }^{42}$ See Concluding observations of the Human Rights Committee: Canada CCPR/C/79/Add.105, 07/04/99, <www.unhchr.ch/tbs/doc.nsf/(Symbol)/e656258ac70f9bbb802567630046f2f2?Opendocum ent.> Visited on 13 July 2004

${ }^{43}$ See e.g., Amnesty International Report 2004 <web.amnesty.org/report2004/index-eng> visited on 15 July 2004. 
contexts of different states' legal systems, socio-economic and political structure, culture, histories and religion. ${ }^{44}$ Such an approach would stress the internal law of states as well as foreign and comparative law and international law would be relegated to a peripheral role. ${ }^{45}$

In today's world the above approach would be largely untenable“...since the second world war it would be inadequate or even misleading to develop a framework for the study of human right in many countries without including as a major ingredient the international and political aspects of the field: laws, processes and institutions." ${ }^{46}$ The comprehensive standards that are today known as human rights are largely a development of international law and relations and many of the organisations working towards the realisation of the aspirations of the human rights movement are creations of that body of law. It would therefore be impossible to grasp the character of the human rights movement without a basic knowledge of international law, its standard setting and other contributions to it. ${ }^{47}$

Given then that international human rights treaties are designed to protect individuals who are primarily subjects of domestic laws and the consequent expectation of domestic implementation, it is difficult to mark a clear boundary between national and international institutions and processes. ${ }^{48}$ "Internal or comparative approaches to human rights law and the truly international aspects of human rights are now rarely 'split'." 49 Admittedly, there are contrary views to the above. In a number of countries, the tendency is to look to the constitution as the primary law of the land for human rights standards. Indeed, in a number of Australian cases, the constitution is used in seeking to prevent the application of human rights treaties in the country. Notwithstanding, in my opinion, international law standards remain the reference point for human rights standards. One of the roles of professional organisations as would be discussed below is to ensure that lawyers are trained in international human rights standards.

\footnotetext{
${ }^{44}$ See generally H. Steiner and P. Alston International Human Rights in Context Law, Politics, Morals (Oxford University Press, Oxford, 2000) p.56

${ }^{45}$ Ibid.

${ }^{46}$ Ibid, p. 57

${ }^{47}$ Ibid.

${ }^{48}$ See H. Steiner “International Protection of Human Rights” in M. Evans' International Law (ed.) (Oxford University Press, Oxford, 2003) p. 758

${ }^{49}$ Supra note 44, p.57
} 


\subsection{THE LIMITATIONS THAT NECESSITATE THE QUEST FOR ALTERNATIVE WAYS TO IMPLEMENT THE TREATIES}

This interrelationship of international and domestic law entails an interesting implementation challenge. As we have seen above, the commitment to implementation on the part of a number of states does not always parallel treaty expectations. Put more directly: the motivation for the treaties implementation is international but international law with its mechanisms is limited in its reach into domestic jurisdictions to stimulate implementation. The Reasons Include:

\subsubsection{Independence/Sovereignty of States}

Though the terms sovereignty and independence are treated as synonymous here, some texts indicate some slight difference in meaning between the two terms. ${ }^{50}$ Independence is "...the capacity of a state to provide for its own well-being and development free from the domination of other states, providing it does not impair or violate their legitimate rights." ${ }^{51}$ It is perhaps the most outstanding characteristic of statehood. ${ }^{52}$ In international law, the main corollaries of sovereignty include the right of a state to exercise jurisdiction over its territory and permanent population; the right of selfdefence; and the duty not to interfere in the internal affairs or the exclusive jurisdiction of other sovereign states. ${ }^{53}$ "At its very threshold and to this day, the human rights movement has inevitably confronted claims based on conceptions of sovereignty." 54 Of all the implications of sovereignty, domestic jurisdiction or non-interference thereof is the most taunted. For example, "The HRC initially refused to interpret its Article 40 mandate as authorising the issue of a consensus evaluation on a particular state's report and subsequent dialogue. Some early HRC members...felt that such a practice would unduly interfere with a state's internal affairs." 55 Today it is believed that issues related to human rights and racial oppression do not fall within the closed category of domestic jurisdiction. ${ }^{56}$ Doubtlessly, regarding human rights, international law has begun to affect the hitherto exclusive jurisdiction of a state's treatment of its nationals. Judge Krylov in his dissenting opinion in Interpretation of Peace Treaties with Bulgaria,

\footnotetext{
${ }^{50}$ See e.g., H. Steiner and P Alston Supra, note 44, p.574

${ }^{51}$ See M. N. Shaw Supra note 1, p.189

${ }^{52}$ Ibid

53 See generally M. N. Shaw Ibid

${ }^{54}$ H. Steiner and P. Alston Supra, note 44, p.572

${ }^{55}$ S. Joseph et al Supra note 8, p.12

${ }^{56}$ M. N. Shaw Supra note 1, p. 191
} 
Hungary and Romania ${ }^{57}$, maintained that the question of human rights and fundamental freedoms, which, Bulgaria, Hungary and Romania were alleged to have failed to observe, was a problem of the functioning of the judicial and administrative authorities of those States. That there was no doubt that the question so defined belonged to the essentially domestic jurisdiction of the State and, as such, was out of the jurisdiction of the ICJ. ${ }^{58}$ The Advisory opinion however did not turn on this assertion and as such, the assertion could not be regarded as a legal enunciation emanating from that case. As, the majority rightly pointed out in the case, the question before the court as to the obligation of the three states to carry out 'the provisions of the articles' refers only to the articles providing for the settlement of disputes. ${ }^{59}$ Judge Krylov's position nonetheless deserves mention since I believe that the position found support among states at that time. It is doubtful that the same position would enjoy similar support today.

In the Case Concerning Military and Paramilitary Activities in and Against Nicaragua (Nicaragua v. United States of America) ${ }^{60}$ Judge Schwebel stated that

\begin{abstract}
"There is nothing to debar a State - or a revolutionary junta entitled to bind the State - from undertaking obligations towards other States in respect of matters which otherwise would be within its exclusive jurisdiction. Thus, under the Statute of the Council of Europe, every Member of the Council of Europe 'must accept the principles of the rule of law and of the enjoyment by all persons within its jurisdiction of human rights and fundamental freedoms' (Art. 3). Any Member which has seriously violated Article 3 may be suspended from its rights of representation. The history of the Council of Europe demonstrates that these international obligations are treated as such by the Council; they may not be avoided by pleas of domestic jurisdiction and nonintervention., ${ }^{61}$
\end{abstract}

This statement fairly represents the contemporary view on the position of human rights as they relate to exclusive domestic jurisdiction. Whether the truthfulness of this view supports the argument proffered by judge Schwebel in the Nicaragua case is a different matter that cannot be addressed here.

Unfortunately, in practice the effect of this position is sometimes disappointing. State sovereignty remains a barrier to the reach of international human rights system into the domestic sphere. "It should then be no surprise that the traditional defences of sovereignty and domestic jurisdiction are asserted today more strongly against the powers or actions of international institutions that involve implementation, enforcement, or dispute resolution...”62

57 1950 I.C.J. 65 Para. 105

${ }^{58}$ Ibid, Para. 111

${ }^{59}$ Ibid Para. 75

${ }^{60} 1986$ I.C.J. 14

${ }^{61}$ Ibid, Para. 383

${ }^{62}$ H. Steiner and P Alston Supra, note 44, p.562 


\subsubsection{Lack of Incentive for Inter-State Complaints}

Connected to the foregoing are the problems relating to the distinctive features of enforcing international law. Generally, violations of treaty norms are primarily resisted via inter-state action. A state or group of states would bring the violation to the attention of either an international tribunal like the ICJ or international institutions like the organs of UN for political and other pressures on the violating states. Accordingly, the six human rights treaties under consideration made special provisions for inter-state complaints. Inter-state complaints have however not worked well regarding the six partly because human rights treaties are very different from say trade agreements. Therefore, state parties to human rights treaties lack the material incentives to act against treaty violating states. ${ }^{63}$

\footnotetext{
"The violation consists in Y's abuse of its own citizens. Why should state $\mathrm{X}$ invest its energies in trying to persuade state $\mathrm{Y}$ to stop such conduct? It would generally be foolish to assume that sustained inquiry into Y's abuses, let alone serious pressures and sanctions against $\mathrm{Y}$, would originate in $\mathrm{X}$ or other state parties, which at most might suspend economic or military aid to the delinquent state."64
}

There are however many examples of inter state action emanating from other major human rights instruments and other judicial procedures. For instance, n 22 May 1994, Cyprus brought a complaint against Turkey under the European Convention on Human Rights ${ }^{65}$ alleging violation of a number of the articles of the Convention concerning the Turkish invasion and occupation of Northern Cyprus. The European court of Human Rights then held inter alia that the applicant government, Cyprus had locus standi and legitimate legal interest in having the merits of the application examined. The Court also held that Turkey had violated several articles of the convention. ${ }^{66}$

\subsubsection{Incorporation of Human Rights Treaties}

The best and primary practice under the obligation to 'give effect' to the treaties is the incorporation of the treaties into the domestic legal system for dualist states ${ }^{67}$ and if I use incorporation as one of the indices of domestic implementation, the $1999-2000$ study $^{68}$ will reveal an implementation

\footnotetext{
${ }^{63}$ H. Steiner and P Alston Supra, note 44, p.562

${ }^{64}$ Ibid.

${ }^{65}$ Convention for the Protection of Human Rights and Fundamental Freedoms 1950

${ }^{66}$ See Cyprus V. Turkey (2002) 35 E.H.R.R. 30 ECHR

${ }^{67}$ Dualist states are those in which treaties do not become part of the national law upon ratification or accession but needs formal incorporation by an act of parliament.

${ }^{68}$ Heyns, Supra note 3, p. 490 (the entire article is on the findings of the study)
} 
challenge. Out of the seven ${ }^{69}$ dualist states surveyed, only one ${ }^{70}$ had incorporated the human rights treaties into domestic law. ${ }^{71}$ The absence of direct incorporation leaves a good part of the treaties, the treaty monitoring bodies' jurisprudence and procedure outside the purview of the judicature. A number of Canadian cases buttress this point; an example is Ahani v. $R^{72}$ Where Dambrot J. Stated:

\begin{abstract}
"Canada has ratified, but not implemented into domestic legislation the International Covenant on Civil and Political Rights, 1966. It has also acceded to the Optional Protocol to the Covenant... While Canadian courts often look to international law when seeking the meaning of the Canadian Constitution, it is beyond dispute that international treaties and conventions are not part of Canadian law, and international treaty norms are not binding in Canada, unless they have been incorporated into Canadian law by enactment."73
\end{abstract}

The court went ahead to uphold the removal of Mr. Ahani, a convention refugee whose appeal against removal was pending before the Human Rights Committee, which has requested Canada to stay the execution of the removal pending the examination of Mr. Ahani's communication. I must however qualify the use of incorporation as an index in evaluating implementation because the non-incorporation of the ICCPR for example will not always amount to a violation of Article 2 since a state party can still give effect to the provisions of the treaty by other legislative measures apart from direct incorporation. The most common example is the constitutional bills of rights adopted by most states, which usually give effect to at least some of the provisions of the major human rights treaties. ${ }^{74}$ However, most human rights lawyers would prefer direct incorporation since most constitutional bills of rights and other forms of domestic law transformation are incomplete when compared to the major human rights treaties, bills of rights tend to concentrate on civil and political rights and most predate some of the major human rights treaties. In addition, direct incorporation will lead to ease of interpretation, as courts would more easily have direct access to the relevant travaux préparatoires, Treaty Body jurisprudence, the works of international law scholars and the decisions of courts of other jurisdiction on the same treaty.

\title{
2.4 MEETING THE CHALLENGE
}

This thesis has so far attempted to show that the treaties were designed to have primary implementation at the domestic level. That low-level of

\footnotetext{
${ }^{69}$ Australia, Canada, Finland, India, Jamaica, South Africa, Zambia.

${ }^{70}$ Finland

${ }^{71}$ See Heyns, Supra note 3, p. 490 (the entire article is on the findings of the study)

722002 CarswellOnt 83

${ }^{73}$ Ibid, paras. 17-19

${ }^{74}$ E.g., Part IV, Constitution of the Federal Republic of Nigeria (1999) < www.nigerialaw.org/ConstitutionOfTheFederalRepublicOfNigeria.htm> visited on 6 July 2004.
} 
domestic implementation remains a challenge in a number of countries; that low-level domestic implementation can negatively affect the international implementation mechanisms and that international law is limited in its reach into domestic spheres for the stimulation of implementation. What further steps can then be taken to meet the challenges of implementing modern international human rights law? Doubtlessly, no one scholarly work can provide all the answers to the above question. However, noting the problems faced by a number of state governments regarding implementation and the limitations of the international mechanisms to intervene or assist. One obvious way forward is concerted action on the part of civil society as further complementation of governmental effort at the domestic level. No doubt, primary responsibility for implementation remains that of each government.

The 1993 World Conference on Human Rights reaffirmed inter alia that education and the dissemination of proper information on human rights would play an important role in the promotion and respect for human rights. $^{75}$ Similarly, several scholars have stated that education and awareness raising is fundamental to achieving respect for human rights. ${ }^{76}$ Specifically on implementation, this time of international humanitarian law, Kalshoven and Zegeld stated. "Of all methods for improving implementation of humanitarian law, instruction and education are probably the most promising ones. In effect all other methods, unless combined with instruction and education, are doomed to fail." 77 There are indeed differences between the implementation expectations of IHL and international human rights law but the statement holds true for both.

For education and other social pressure for change particularly in the area of policy and legislation, professional and civil society organisations as part of the working of every state, need to expend considerable effort for the most effective response to the implementation problem. Their effort must complement that of the government since the political process in a number of states will always need the boost that can thus be provided by civil society. As would be seen in the following sections, some of the advantages of focusing on civil society include the building of pervasive expectation in the general public without the need for formal state action. The resultant human rights based public opinion has the potential of positively influencing formal implementation action from the government. Examples of this abound. "Pressure and lobbying from civil society have facilitated ratification of treaties (e.g. India with respect to CEDAW and CRC; Jamaica with respect to CEDAW). ${ }^{78}$ It is my belief also that professional organisations like law teachers associations can autonomously improve the

\footnotetext{
75 See Article 33, Vienna Declaration and programme of Action 1993

${ }^{76}$ See eg., A. Eide and G. Alfredsson 'Introduction', in G. Alfredsson and A. Eide (eds.) The Universal Declaration of Human Rights (Kluwer Law International, The Hague, 1999) p. xxix; P. Arajärvi 'Article 26', in G. Alfredsson and A. Eide (eds.) The Universal Declaration of Human Rights (Kluwer Law International, The Hague, 1999) p. 555

${ }^{77}$ F. Kalshoven and L. Zegveld Constraints on the Waging of War an Introduction to International Humanitarian Law (ICRC, Geneva, 2001) p. 70.

${ }^{78}$ C. Heyns and F. Viljoen Supra note 3, p. 494.
} 
effectiveness of implementation of the treaties. One way is by facilitating a human rights culture that would in turn affect the general implementation climate in a state. In a number of countries for example, the courts have taken the view that human rights treaties do not need special incorporation to have effect after they have been ratified by the state provided such a treaty is not totally against the law. On the effect of lack of incorporation Ramadhani J. A., in the Tanzanian case of Transport Equipment and another $v$. D, P. Valambhia, ${ }^{79}$ held:

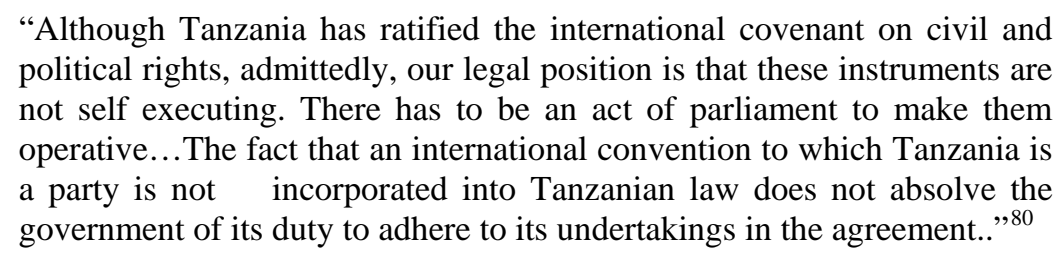

This represents an alteration of positions since Tanzania is one of those countries where judges traditionally refuse to implement treaties they consider non-self-executing. It is however, an example of the type of attitude shifts that law teachers can and should hope to influence alongside the other efforts of the state.

${ }^{79}$ Civil Application No. 19 of 1993 Court of Appeal, Dar es salaam.

${ }^{80}$ Ibid. 


\section{THE LEGAL BASIS IN INTERNATIONAL LAW FOR PROFESSIONAL AND CIVIL SOCIETY ORGANISATIONS PARTICIPATION}

The major human rights treaties including the ones under consideration were adopted by the UN General Assembly and the bulk of the institutions that form the international mechanisms of implementation and monitoring are part of the UN system. Furthermore, some of the clearest mandate in international law for the said participation are contained in a number of resolutions and declarations of the organs of the UN, notably the General Assembly and the Economic and Social Council. I will accordingly begin this section by outlining the relevant provisions of the UN Charter. This will aid in bringing out the authority and value of those 'soft laws' and the weight to be attached to them.

\subsection{THE CHARTER PROVISIONS}

Article 1 (3) stipulates one of the purposes of the United Nations as being "To achieve international co-operation in solving international problems of an economic, social, cultural, or humanitarian character, and in promoting and encouraging respect for human rights and for fundamental freedoms for all without distinction as to race, sex, language, or religion...”. ${ }^{81}$ By Article I (4), the Charter makes it clear that the UN is to be a centre for harmonizing the actions of nations for the common ends of the UN including notably, respect for human rights. ${ }^{82}$ As part of the provisions on the functions and powers of the General Assembly, Article 13 (1) (b) empowers that organ to initiate studies and make recommendations for promoting international cooperation in the economic, social, cultural, educational, and health fields. In addition, assisting in the realization of human rights and fundamental freedoms for all without distinction as to race, sex, language, or religion. ${ }^{83}$

Viewed from the perspective of the above provision, the various General Assembly declarations and resolutions that explicitly provide for the participation of professional and civil society organisations in the implementation of the treaties are themselves part of the implementation of the UN Charter. Moreover, where unenforceable particularly at the domestic

\footnotetext{
${ }^{81}$ Charter of the United Nations 1945

${ }^{82} \mathrm{Ibid}$

${ }^{83}$ UN Charter Supra note 81, Article 13 (1) (b).
} 
sphere, the declarations and resolutions are to serve as necessary guide in all legal considerations of the role of the organisations in question. The foregoing stipulations are also to some extent applicable to the Economic and Social Council of the UN in the light of Article 62 (1) and (2) of the Charter. ${ }^{84}$ Suffice it to say however, that the General Assembly, the Economic and Social Council and the Commission on Human Rights are the responsible organs for decision- and policy-making for the promotion and protection of all human rights and the organs are products of the UN Charter. The declarations discussed below are also direct results of this broad mandate.

\subsection{THE UN DECLARATIONS AND RESOLUTIONS}

It is important to note here that declarations and resolutions are generally not legally binding instruments. However, they contain principles and rights that are based on human rights standards enshrined in other legally binding international instruments. ${ }^{85}$ As indicated above, some of the declarations to be examined are inextricably linked to the mandate of organs created by the UN Charter. It is sometimes argued that these "non-binding instruments" form a special category termed 'soft law' ${ }^{86}$ "This terminology is meant to indicate that the instrument or provision in question is not itself 'law', but its importance within the general framework of international legal development is such that particular attention requires to be paid to it." 87

\subsubsection{Declaration on the Right and Responsibility of Individuals, Groups and Organs of Society to Promote and Protect Universally Recognized Human Rights and Fundamental Freedoms}

\footnotetext{
84 UN Charter Supra note 81, Article 62 (1) and (2): (1) The Economic and Social Council may make or initiate studies and reports with respect to international economic, social, cultural, educational, health, and related matters and may make recommendations with respect to any such matters to the General Assembly to the Members of the United Nations, and to the specialized agencies concerned. (2) It may make recommendations for the purpose of promoting respect for, and observance of, human rights and fundamental freedoms for all.
}

85 See generally OHCHR 'Declaration on Human Rights Defenders' $<$ www.ohchr.org/english/issues/defenders/declaration.htm> visited on 29 July 2004

${ }^{86}$ See generally M. N. Shaw Supra, note 1, p. 110

${ }^{87}$ Ibid 
Article 16

Individuals, non-governmental organizations and relevant institutions have an important role to play in contributing to making the public more aware of questions relating to all human rights and fundamental freedoms through activities such as education, training and research in these areas to strengthen further, inter alia, understanding, tolerance, peace and friendly relations among nations and among all racial and religious groups, bearing in mind the various backgrounds of the societies and communities in which they carry out their activities.

Article 17

In the exercise of the rights and freedoms referred to in the present Declaration, everyone, acting individually and in association with others, shall be subject only to such limitations as are in accordance with applicable international obligations and are determined by law solely for the purpose of securing due recognition and respect for the rights and freedoms of others and of meeting the just requirements of morality, public order and the general welfare in a democratic society.

\section{Article 18}

1. Everyone has duties towards and within the community, in which alone the free and full development of his or her personality is possible.

2. Individuals, groups, institutions and non-governmental organizations have an important role to play and a responsibility in safeguarding democracy, promoting human rights and fundamental freedoms and contributing to the promotion and advancement of democratic societies, institutions and processes.

3. Individuals, groups, institutions and non-governmental organizations also have an important role and a responsibility in contributing, as appropriate, to the promotion of the right of everyone to a social and international order in which the rights and freedoms set forth in the Universal Declaration of Human Rights and other human rights instruments can be fully realized.

The elaboration of this Declaration, frequently abbreviated as "The Declaration on human rights defenders", began in 1984 and ended with the adoption of the text by the General Assembly in 1998 on the occasion of the fiftieth anniversary of the Universal Declaration of Human Rights. ${ }^{88}$ It has been said to be a strong, very useful and pragmatic text. ${ }^{89}$ The Declaration succinctly captures the essence of our discourse and contains the clearest provisions on the participation of professional and civil society organisations in the implementation of international human rights treaties particularly in the provisions excerpted above.

Article 3 of the Declaration provides that:

"Domestic law consistent with the Charter of the United Nations and other international obligations of the State in the field of human rights and fundamental freedoms is the juridical framework within which human rights and fundamental freedoms should be implemented and enjoyed and within which all activities referred to in the present Declaration for the

\footnotetext{
${ }^{88}$ Supra note 69.

89 Ibid.
} 
promotion, protection and effective realization of those rights and freedoms should be conducted." 90

It is on this basis that it went ahead to address, not just states and traditional human rights defenders and activists but everyone and emphasizes a global human rights movement that involves us all. This Declaration would prove a veritable tool and source of inspiration in the hands of all professional organisations and civil society as would be seen hereunder.

Article 16 above emphasises the important role of individuals, nongovernmental organisations and relevant institutions (which of course include professional organisations) in contributing to public enlightenment on questions relating to all human rights and fundamental freedoms through education, training, research and similar activities. ${ }^{91}$ If properly employed, this article provides necessary background for the participation of the organisations in providing the type of human rights education that would facilitate implementation.

Article 18 (2) emphasises the role and responsibility of Individuals, groups, institutions and non-governmental organizations in safeguarding democracy, promoting human rights and fundamental freedoms and contributing to the promotion and advancement of democratic societies, institutions and processes. $^{92}$ Paragraph 3 of the same article in turn emphasises the role and responsibilities of the same individuals and groups to promote a social and international order in which the rights and freedoms set forth in the Universal Declaration of Human Rights and other human rights instruments can be fully realized. ${ }^{93}$

The two paragraphs necessarily translate into activities such as social and political pressures, lobbying and other democratic processes that would bring about apposite reforms including legislative and judicial, which would in turn amount to a more effective implementation of the treaties. Article 17 precludes states from imposing on the individuals and groups limitations other than those that "....are in accordance with applicable international obligations and are determined by law solely for the purpose of securing due recognition and respect for the rights and freedoms of others and of meeting the just requirements of morality, public order and the general welfare in a democratic society." 94 A careful reading of the articles quoted above begins to reveal at least a moral and political duty and responsibility on civil society to play a role in promoting human rights, including treaty implementation. This duty would be further analysed below.

\footnotetext{
90 Declaration on the Right and Responsibility of Individuals, Groups and Organs of Society to Promote and Protect Universally Recognized Human Rights and Fundamental Freedoms, General Assembly Resolution A/RES/53/144, 8 March 1999.

${ }^{91}$ Ibid, Article 16.

${ }^{92}$ Ibid, Article 18 (2).

93 Ibid, para. 3.

${ }^{94}$ Ibid, Article 17.
} 


\title{
3.2.2 Basic Principles on the Role of Lawyers
}

These principles were adopted by the eighth United Nations Congress on the prevention of crime and the treatment of offenders. They were formulated to assist member states of the UN in their task of promoting and ensuring the proper role of lawyers in view of one of the Charter purposes of achieving international cooperation in promoting and encouraging respect for human rights and fundamental freedoms without discrimination. ${ }^{95}$ Article 9 stipulates that

\begin{abstract}
"Governments, professional associations of lawyers and educational institutions shall ensure that lawyers have appropriate education and training and be made aware of the ideals and ethical duties of the lawyer and of human rights and fundamental freedoms recognized by national and international law."96
\end{abstract}

The article, in addition to governments, directly addresses professional associations of lawyers and educational institutions. It underscores the importance of lawyers in the global human rights movement and clearly indicates the role of professional associations of lawyers and legal education providers, which would include all the law faculties in member states' universities and the various bar schools and inns of courts that provide training in procedural law. Although the Basic Principles do not constitute a binding legal instrument, Article 9 above so articulates the role expected of legal professional organisations that no such organisation or institute could reasonably graduate students that are not grounded in the ethical duties of lawyers and the ideals of human rights and fundamental freedoms.

\subsubsection{The Vienna Declaration and Programme of Action}

The UN World Conference on Human rights adopted the Declaration on 25 June 1993. The Conference and the resultant declaration is not always lauded as a resounding success particularly by the NGOs not least because of a limiting clause in paragraph 38 that encourages state protection for NGOs and their members genuinely involved in human rights. ${ }^{97}$ According to $\mathrm{M}$. Schechter, "the notion that national governments will decide upon the genuineness of their own human right organisations and make that the basis for affording or denying them the protection of national law is especially worrying in the field of human rights." ${ }^{98}$ Notwithstanding, the Declaration contains provisions that can inspire professional and civil society

\footnotetext{
${ }^{95}$ See Basic Principles on the Role of Lawyers, Eighth United Nations Congress on the Prevention of Crime and the Treatment of Offenders, Havana, 27 August to 7 September 1990, U.N. Doc. A/CONF.144/28/Rev.1 at 118 (1990), Preamble, para. 1 and 11.

${ }^{96}$ Ibid, Article 9

${ }^{97}$ See e.g., M. Schechter 'UN-Sponsored world Conference in the 1990s' in M. Schechter (ed.) United Nations-sponsored world conferences: Focus on impact and follow-up (United Nations University Press, Tokyo, 2001) p. 35.

${ }^{98}$ Ibid.
} 
organisations participation in the implementation of the treaties. The Declaration is unequivocal regarding the role of civil society organisations, particularly NGOs towards the full realisation of human rights. Beyond governments and intergovernmental organisations; groups, individuals, institutions and non-governmental organisations are severally urged by the declaration to inter ali, cooperate in creating favourable conditions for the full and effective enjoyment of human rights at the national, regional and international levels. ${ }^{99}$ Intensify effort towards eliminating all forms of racial discrimination. ${ }^{100}$ Intensify their efforts for the protection and promotion of human rights of women and the girl-child. ${ }^{101}$

Paragraph 38 specifically "recognizes the important role of nongovernmental organizations in the promotion of all human rights and in humanitarian activities at national, regional and international levels.”102 The World Conference on Human Rights also in the same paragraph appreciated the contribution of NGOs to increasing public awareness of human rights issues, the conduct of education, training and research, and the promotion and protection of all human rights and fundamental freedoms. The conference also appreciated the contribution of non-governmental organizations to the process of standard setting, which was noted as the primary responsibility of states. In underlining the importance of objective, responsible and impartial information about human rights and humanitarian issues, the conference in paragraph 39 encourages the increased involvement of the media, for whom freedom and protection should be guaranteed within the framework of national law.

\subsubsection{The Universal Declaration of Human Rights and the Vienna Declaration and Programme of Action on Human rights Education}

The UDHR upheld the right to education in Article 26 and in paragraph two of the same Article, outlined the content of education as follows:

"Education shall be directed to the full development of the human personality and to the strengthening of respect for human rights and fundamental freedoms. It shall promote understanding, tolerance and

\footnotetext{
${ }^{99}$ See Vienna Declaration and Programme of Action, World Conference on Human Rights, Vienna, 14-25 June 1993, A/CONF. 157/23, para. 13, www.unhchr.ch/huridocda/huridoca.nsf/(Symbol)/A.CONF.157.23.En?OpenDocument visited on 29 July 2004.

${ }^{100} \mathrm{Ibid}$, para. 15.

${ }^{101}$ Ibid, para. 18.

${ }^{102} \mathrm{Ibid}$, para. 38
} 
friendship among all nations, racial or religious groups, and shall further the activities of the United Nations for the maintenance of peace.”103

Undoubtedly, Article 26 (2) above inter alia calls for human rights education. ${ }^{104}$ However, neither the travaux préparatoires nor the language of the text gives the indication that Article 26 (2) addresses professional and civil society organisations. Indeed, the VDPA, in reiterating the provisions of the UDHR and CESCR and emphasising the importance of incorporating the subject of human rights in education programmes, outlined mainly the duty of states. However, the last preambular paragraph of the UDHR removes every doubt as to the role of professional and civil society organisations as one of the addressees of Article 26. The paragraph proclaims the UDHR as a common standard of achievement and enjoins every individual and every organ of society to keep the Declaration constantly in mind while striving by teaching and education to promote respect for the rights and freedoms and their universal and effective recognition and observance. ${ }^{105}$ Notwithstanding Koskenniemi's statement on preambles indicating with certainty what is left outside the text, he went ahead to explain that preambles play an ambiguous role, but through it all, they support, encourage and explain. "When in doubt, consult the preamble! When things become blocked, the preamble opens them up. The preamble is the supplement that aids in the comprehension of the text." ${ }^{106}$ Accordingly, the above provisions should be brought to the attention of all education providers particularly those directly involved in legal education and such providers should be enjoined to keep the provisions constantly in mind as a minimum standard for the content of education. See section 3.4 below for more discussion on the duty of professional and civil society organisations to provide human rights education.

\subsubsection{The VDPA and the Resolution on UN Technical Assistance/Cooperation and Advisory Services}

The UN Technical Cooperation Programme in the Field of Human Rights has been engaged since 1955 in assisting States, at their request, in the building and strengthening of national structures that have a direct impact on the overall observance of human rights and the maintenance of the rule

\footnotetext{
103 The Universal Declaration of Human Rights, General Assembly Resolution 217A (III) of 10 December 1948, Article 26 (2).

${ }^{104}$ See also P. Arajärvi, supra note 76

105 But see M. Koskenniemi 'The Preamble of the UDHR', in G. Alfredsson and A. Eide (eds.) The Universal Declaration of Human Rights (Kluwer Law International, The Hague, 1999)p. 27. "The one thing that is certain about the preamble is that whatever it contains was not accepted as part of the text itself”

106 Ibid
} 
of law. The programme inter alia, focuses on incorporation of international human rights standards in national laws and policies; building and strengthening national institutions; formulation of national plans of action; human rights education and training and the promotion of a human rights culture. ${ }^{107}$ One of the important developments of the 1990s in the area of UN technical cooperation programme is the establishment of the Office of the UN High Commissioner for Human Rights. This development is traceable to the Vienna Declaration and Programme of action, 1993. Paragraph 34 of the Declaration urged strengthening of the programmes of advisory services and technical cooperation under the Centre for Human Rights (The Centre for Human Rights is now abolished). ${ }^{108}$ While Paragraph 18 contains the major provision as follows:

"The World Conference on Human Rights recommends to the General Assembly that when examining the report of the Conference at its fortyeighth session, it begin, as a matter of priority, consideration of the question of the establishment of a High Commissioner for Human Rights for the promotion and protection of all human rights." 109

This recommendation became a reality when the General Assembly, in 1994, affirming its commitment to the VDPA, passed a resolution creating the office High Commissioner for the promotion and protection of all human rights. ${ }^{110}$ Paragraph 4 (d) and (e) outlines the functions of the OHCHR to include providing, through the Centre for Human Rights (now abolished) of the Secretariat and other appropriate institutions, advisory services and technical and financial assistance. This is to be done at the request of the State concerned and, where appropriate, the regional human rights organizations, with a view to supporting actions and programmes in the field of human rights. In addition, to coordinate relevant United Nations education and public information programmes in the field of human rights. ${ }^{111}$ Today "Technical cooperation is a key area of activity of the Office of the High Commissioner for Human Rights (OHCHR), an area in which the Office makes a substantial contribution to integrated development cooperation, realization of the right to development... and in promoting and encouraging respect for human rights and fundamental freedoms for all.”112 The impact of the technical cooperation programme as they relate to this topic would be briefly assessed at the concluding part of the thesis.

\footnotetext{
${ }^{107}$ See Office of the High Commissioner for Human Rights 'Technical Cooperation' <www.unhchr.ch/html/menu2/techcoop.htm>

${ }^{108}$ VDPA, Supra, note 99, para. 34.

${ }^{109}$ Ibid, para. 18.

${ }^{110}$ General Assembly resolution 48/141 of 20 December 1993.

${ }^{111}$ Ibid, para. 4 (d) and (e)

112 OHCHR Supra, note 107
} 


\subsection{HUMAN RIGHTS TREATIES PROVISIONS AND INTERPRETATION BY TREATY BODIES GENERAL COMMENTS}

Treaties primarily regulate relations between nations; human rights treaties are no exception to this rule. Accordingly, one does not expect many references to implementation methods outside the direct involvements of states. Nevertheless, there are a few references in the rights and freedoms in some of the treaties that form a good backdrop for professional and civil society organisations participation in the implementation process of all the treaties. The references also afford protection for the participating organisations.

\subsubsection{The International Covenant on Economic Social and Cultural Rights and Education}

The ICESCR devotes two articles to the right to education, articles 13 and 14. Article 13, the longest provision in the Covenant, is the most wideranging and comprehensive article on the right to education in international human rights law. ${ }^{113}$ Article 13 (1) of the CESCR provides:

\footnotetext{
"The States Parties to the present Covenant recognize the right of everyone to education. They agree that education shall be directed to the full development of the human personality and the sense of its dignity, and shall strengthen the respect for human rights and fundamental freedoms. They further agree that education shall enable all persons to participate effectively in a free society, promote understanding, tolerance and friendship among all nations and all racial, ethnic or religious groups, and further the activities of the United Nations for the maintenance of peace." 114
}

Notably for our purpose, the article stipulates that education shall strengthen respect for human rights and fundamental freedom. In its General Comment No.13, The Committee on Economic Social and Cultural Rights, calling education an empowerment right, noted, "Education is both a human right in itself and an indispensable means of realizing other human rights."115 In paragraph 38, of the general comment, the Committee stated that based on its examination of states reports, it has formed the view that the right to education can only be enjoyed if accompanied by the academic freedom of

\footnotetext{
${ }^{113}$ Committee on Economic , Social and Cultural Rights 'General Comment No. 13', E/C.12/1999/10, 08/12/1999, para. 2

${ }^{114}$ International Covenant on Economic Social and Cultural Rights, 1966 , <www.unhchr.ch/html/menu3/b/a_cescr.htm> visited on 6 August 2004.

115 Supra note 95 , para 1
} 
staff and students. ${ }^{116}$ Acknowledging that academic freedom is not specifically mentioned in Article 13, The Committee emphasized that staff and students throughout the education sector, particularly the higher education sector, are entitled to such freedom.

The Committee outlined the content of "academic freedom" inter alia as follows. "Members of the academic community, individually or collectively, are free to pursue, develop and transmit knowledge and ideas, through research, teaching, study, discussion, documentation, production, creation or writing" 117 The term also includes: the liberty of members of the academic community to express freely opinions about the institution or system in which they work; fulfilment of functions without discrimination or fear of repression by the State or any other actor; participation in professional or representative academic bodies; and enjoyment of all the internationally recognized human rights applicable to other individuals in the same jurisdiction.

Were states to abide by the obligation of Article 13 as interpreted by the Committee, and members of the academic community in turn observe the content of the article in addition to Article 26 of the UDHR in line with their duties as envisaged in the provisions and the relevant Declarations discussed above. There would then be no need to wait for formal governmental policy pronouncement before the members of the academic community can actively engage in the vital task of inculcating the needed human rights culture into the society particularly in states where the government has yet to start addressing such a culture. It becomes easy then to foresee a strengthened domestic environment for effective implementation of all human rights standards, particularly the treaties. The position of the academic community in each state party is further reinforced by the provision of Article 13 (4), which states that:

"No part of this article shall be construed so as to interfere with the liberty
of individuals and bodies to establish and direct educational institutions,
subject always to the observance of the principles set forth in paragraph I
of this article and to the requirement that the education given in such
institutions shall conform to such minimum standards as may be laid
down by the State."118

The article makes for non-state ownership of educational institutions subject to such minimum standards as may be laid down by the state. Needless to say, such minimum standards such as admission requirements, curricular and accreditation, shall always conform to universally recognized human rights standards like the education objectives listed in Article 13 (1) CESCR, else the state would be in breach of her CESCR obligations. Understandably, funding could be a factor in the full enjoyment of the provision.

\footnotetext{
${ }^{116}$ Ibid, para. 38.

${ }^{117}$ Ibid, para. 39.

${ }^{118}$ ICESCR, Supra note 114, Article 13 (4)
} 


\title{
3.3.2 The International Covenant on Civil and Political Rights
}

The ICCPR contains some of the strongest guarantees for the participation of civil society and professional organizations in the implementation of the treaties. Articles 19, 21, 22 and 25 provide for freedom of opinion and expression, the right to peaceful assembly, the right to freedom of association and the right to take part in the conduct of public affairs respectively. ${ }^{119}$ These rights are of general application and are indispensable in the realization of other human rights. The Human Rights Committee in its General Comment No. 10 has stated that Paragraph 2 of Article 19 "...requires protection of the right to freedom of expression, which includes not only freedom to "impart information and ideas of all kinds", but also freedom to "seek" and "receive" them "regardless of frontiers" and in whatever medium, "either orally, in writing or in print, in the form of art, or through any other media of his choice".,120 These rights are interrelated. For instance, the right to freedom of expression as outlined above is at the core of the enjoyment of the rights set out in Article 25, according to the HRC, in General Comment No. 25:

\begin{abstract}
"In order to ensure the full enjoyment of rights protected by article 25, the free communication of information and ideas about public and political issues between citizens, candidates and elected representatives is essential. This implies a free press and other media able to comment on public issues without censorship or restraint and to inform public opinion." 121
\end{abstract}

Similarly, as the Committee has stated, "The right to freedom of association, including the right to form and join organizations and associations concerned with political and public affairs, is an essential adjunct to the rights protected by article 25." ${ }^{122}$ In addition, referring to the activities mentioned in Article 25, "This participation is supported by ensuring freedom of expression, assembly and association." ${ }^{123}$ Considering this interrelatedness, it is safe then to state that the conclusions of the Committee on Article 25 are equally true for Articles 19, 21 and 22. Accordingly, the four articles of the ICCPR lie at the core of representative government since according to the committee, "Article 25 lies at the core of democratic

\footnotetext{
${ }^{119}$ See International Covenant on Civil and Political Rights 1966, $<$ www.unhchr.ch/tbs/doc.nsf $>$ visited on 10 August 2004

${ }^{120}$ Human Rights Committee, General Comment No. 10: Freedom of expression (Art. 19): 29/06/83, para. 2 available online at <www.unhchr.ch/tbs/doc.nsf/(Symbol)/2bb2f14bf558182ac12563ed0048df17?Opendocum ent> visited on 10 August 2004

${ }^{121}$ Human Rights Committee, General Comment NO. 25, The right to participate in public affairs, voting rights and the right of equal access to public service (Art. 25): 12/07/96, CCPR/C/21/Rev.1/Add.7, para. 25. Available online at <www.unhchr.ch/tbs/doc.nsf/(Symbol)/d0b7f023e8d6d9898025651e004bc0eb?Opendocu ment> visited on 10 August 2004

${ }^{122}$ Ibid., para. 26

${ }^{123}$ Ibid., para. 8
} 
government based on the consent of the people and in conformity with the principles of the Covenant." ${ }^{124}$ Professional and civil society organisations are therefore further empowered by these rights to participate in developing the necessary climate for the implementation of the human rights treaties by taking part in popular assemblies that have the power to make the necessary decisions and in bodies established to represent citizens in consultation with the government. ${ }^{125}$ Further, these rights empower the exerting of influence through public debate and dialogue through either representatives or the citizens' right and capacity to organise themselves. ${ }^{126}$

\subsection{ARE THERE OBLIGATIONS ON PROFESSIONAL AND CIVIL SOCIETY ORGANISATIONS TO PLAY THE ROLE?}

The instruments discussed above fairly establish a right of professional and civil society organisations to play a role in human rights promotion. The relevant articles of the ICCPR guarantee the freedom of these organisations to exist and operate freely, while the relevant articles of the CESCR, albeit as a limitation clause guarantee the liberty of such existing organisations to establish and direct educational institutions. Taken as a whole, the declarations and the basic principles discussed above represent a clear call and empowerment for these organisations to get on board and promote human rights, which includes facilitating the implementation of the treaties. The question then is whether there is a duty on these groups and organisations to answer the call.

Firstly, does the right of private individuals and groups to establish and run schools include the duty to teach human rights in such schools? My answer is definitely in the affirmative. The liberty to run such schools is guaranteed in Article 13 (4) CESCR, this right cannot be claimed in disregard of the objective of education as enunciated in the same article at paragraph 13 (1) to the effect that education shall be directed inter alia to strengthen respect for human rights as also reiterated in Article 29 (1) (b) CRC. This duty is incumbent on all education providers within the territory of each state party to the above treaties, obviously including professional and civil society organisations. Largely, this may even amount to a legal obligation given that the state party can enforce same should it choose to. But then the chickens have come back to roost since part of the reason for this discourse is that some states are failing in their treaty obligations, including the provision of human rights education in schools. Suffice it then to say that there may well be a treaty-based duty on all education providers to teach human rights based on the positive obligation on states to ensure that education is directed

${ }^{124}$ Ibid., para. 1

${ }^{125}$ See Ibid., para. 6

${ }^{126}$ See Ibid., para.8 
towards strengthening respect for human rights and fundamental freedoms. Article 13 (1) CESCR on the content of education is to be observed within each state party regardless of who is running the schools.

Is there a duty for professional and civil society organisations to participate in human rights treaties implementation as I have suggested in this chapter? Article 29 UDHR, states "Everyone has duties to the community in which alone the free and full development of his personality is possible.” Everyone includes the groups in question and this article begins to throw some light on the question of duty. In discussing this article, T. Opsahl and V. Dimitrijevic concluded that "Duties to the community" belongs wholly to the moral and political sphere and can hardly be translated into law." ${ }^{127}$ If this is true, it is then unnecessary to inquire into whether the instrument articulating the responsibilities of these organisations is legally enforceable or not. Accordingly, I will argue that the UDHR on education; the VDPA; the Declaration on Human Rights Defenders; the Basic Principles on the role of lawyers, all read together with the discussed treaty provisions, reveal at least a moral and political duty on professional and civil society organisations to play the envisaged role.

On human rights education, G. Alfredsson stated,

"While states have undertaken the legal commitments to implement the provisions on human rights education, teachers, researchers, scientists, universities and other institutions of higher education also carry moral and political obligation to the same end.”128

Using the term 'task' $M$. Nowak stipulates that the dissemination of information on the ethics and philosophical foundations of human rights, practical knowledge on protection of one's human rights aimed at reducing the gap between theory and practice is the contemporary tasks for governments, educational facilities, NGOs and intergovernmental organisations. ${ }^{129}$ There is therefore a moral and political obligation on the organisations to participate in the promotion of all human rights including treaty implementation.

\footnotetext{
127 T. Opsahl and V. Dimitrijevic 'Article 29 and 30', in G. Alfredsson and A. Eide (eds.) The Universal Declaration of Human Rights (Kluwer Law International, The Hague, 1999)p.641

${ }^{128}$ G. Alfredsson 'The Right to Human Rights Education' in A. Eide and C. Crause (Eds)'s Economic Social and Cultural Rights A Textbook (Kluwer Law International, The Hague, 2001) p. 282

${ }^{129}$ M. Nowak 'The Right to Education' in A. Eide and C. Crause (Eds)'s Economic Social and Cultural Rights A Textbook (Kluwer Law International, The Hague, 2001) p. 246
} 


\subsection{ILLUSTRATIONS FROM DECIDED CASES}

A few decided cases from different jurisdictions would be instrumental in illustrating the role of civil society in implementation as envisaged by the instruments discussed above as well as in underscoring the nature of change that such civil society participation should seek to achieve.

In the Australian case of Koowarta v. Bjelke-Petersen and Others ${ }^{130}$ The Aboriginal Land Fund Commission contracted to buy a Crown Lease of a pastoral property in Queensland. The Queensland Minister for Lands refused his consent to the transfer of the lease because of a government policy, which was opposed to the acquisition by Aborigines of large areas of land in the State. Koowarta, an Aboriginal, who had been active in arranging the purchase of the land which he expected to be used by himself and other members of his tribe, brought an action against members of the Queensland Government for breaches of ss. 9 and 12 of the Racial Discrimination Act 1975. An Act passed to give effect to the International Convention on the Elimination of all Forms of Racial Discrimination to which Australia is a party. Koowarta sued as a member of a group of Aboriginal people known as the Winychanam Group. This suit was consolidated with another suit brought by the State of Queensland against the Commonwealth of Australia claiming a declaration that the Racial Discrimination Act is ultra vires and invalid since the Act went beyond the power conferred on the parliament by s. 51 (xxvi) and (xxix) of the constitution. The Australian High Court held that the plaintiff was a "person aggrieved" within s. 24 of the Act because his case came within s. 12 and that ss. 9 and 12 were valid laws with respect to external affairs within s. 51(xxix) of the Constitution.

The point of this case is that regardless of the ratification of the International Convention on the Elimination of all Forms of Racial Discrimination by Australia and the incorporation of same into domestic law, a patently discriminatory cabinet policy still stood in the state of Queensland as stated in the Minister for Lands' reason for refusing the permission to wit. "The question of the proposed acquisition of Archer River Pastoral Holding comes within the ambit of declared Government policy expressed in Cabinet decision of September 1972, which stated:'The Queensland Government does not view favourably proposals to acquire large areas of additional freehold or leasehold land for development by Aborigines or Aboriginal groups in isolation.”" ${ }^{131}$ It took the vigorous effort of the Australian judiciary as instigated by civil society to complete the treaty implementation process and give effect to the CERD.

130153 C.L.R. 168

${ }^{131}$ Ibid, P. 176 
In Australian Education Union v Human Rights and Equal Opportunity Commission and Another, ${ }^{132}$ the applicant lodged a complaint with the first respondent alleging that the State of Tasmania, the second respondent has discriminated against certain of its female employees in the provision of superannuation services in breach of s 22 of the Sex Discrimination Act 1984. The Act was passed to give effect to certain provisions of the Convention on the Elimination of All Forms of Discrimination Against Women. The alleged discrimination was based on the State of Tasmania's refusal to allow female teachers, whose service prior to 1969 had become non-contributory because of their resignation in order to bear children, to purchase recognition of that service for superannuation purposes at the favourable rate prescribed by reg. 14 of the 1994 Transitional Regulations. The cost to female teachers of purchasing years of service under reg. 24 of the 1994 Regulations was based on "the full actuarial cost", and is considerably higher than if they had been eligible to purchase "years of service" under reg. 14. The HREOC Inquiry Commissioner dismissed the complaint on the ground that if there had been any discrimination by the State of Tasmania it had not been under s 22 of the Act as alleged but was under s 14 of the Act. That s. 14 is not binding on and does not apply to a State or an instrumentality of a State because of ss 12(1) and 13(1) of the Act.

The Court held that although the payment by an employer of contributions in respect of its employees to a superannuation fund was not the provision of "services" for the purposes of the Act. However, the activities of the trustee of the superannuation fund in investing and administering the fund and in providing benefits to the members of the fund involved the provision of "services". The failure of the Commission to draw that distinction was an error of law. Additionally, that to the extent that conduct by a State or State instrumentality fell within both s 14 (in respect of employment) and s 22 (in respect of services) of the Act, s 13(1) ensured that the State's conduct was not a contravention of s 14. However, pursuant to the express provision in $\mathrm{s}$ 22(2), the conduct would constitute a contravention of s 22. (55C).

Again, we see the completion of the implementation process at the instigation of a civil society organisation, The Australian Education Union $^{133}$. In a common law jurisdiction like Australia, the importance of these judicial pronouncements cannot be overstated. Not only do such successful cases aid in the clarification of the existing law, the holdings constitute a part of the law regarding future cases.

In judicial interpretation of the law, there are sometimes grey areas and margins, in which the adjudicator can exercise discretion one way or the other depending on his/her orientation, convictions and sympathies. In common law countries, these so-called margins have led to judges distinguishing case law of binding precedence and have led to all sorts of

\footnotetext{
13280 FCR 46

${ }^{133}$ See section 4.2.2 for some details on the Australian Education Union and the implementation process
} 
constructive interpretation of the law in the interest of public policy, justice and other legal considerations. In the same spirit, a number of obiter dicta have emerged from the benches of different jurisdictions that have eventually led to positive legal change. My point exactly is that the professional and other civil society organisations addressed in this thesis can and should play a role in encouraging judges and other adjudicators to be human rights oriented in interpreting the law. Where the law gives locus standi to NGOs this can be done through legal means, otherwise non-legal means can be used in sensitising the judges.

In the Canadian case of Ahani $v . R^{134}$, the Applicant, a convention refugee from Iran, was arrested and detained on the ground that he was a member of an inadmissible class because of his membership in a terrorist organization. The Minister of Citizenship and Immigration issued a deportation order for the applicant's removal to Iran, where he feared torture. After exhausting domestic remedies, the applicant filed a communication with the Human Rights Committee for relief under the Optional Protocol to the International Covenant on Civil and Political Rights, and the Committee made a request for interim measures, asking Canada to stay the deportation order until it has considered the applicant's communication.

Since Canada intended to deport the applicant immediately, he applied to the Superior Court for an injunction restraining his deportation pending the Committee's consideration of his communication; the application was dismissed and in Ahani v. $R^{135}$ the subsequent appeal was also dismissed by the Ontario Court of Appeal. The main reason for the dismissal in both instances is that although Canada had ratified both the International Covenant on Civil and Political Rights and the optional protocol, both instruments have not been incorporated into domestic law. Also that the recommendations of the Human Rights Committee are not binding on Canada as a matter of international or domestic law.

In my opinion, there was nothing that could have stopped Dambrot $\mathrm{J}$ in the first instance or the appellate judges from allowing themselves to be persuaded by the reasoning of the Privy Council in Thomas v. Baptiste. ${ }^{136}$ Continued effort from civil society is very likely to contribute to an increase in the number of judges that would be prepared to follow such a cause. Actually, Rosenberg J.A. followed that reasoning in his dissenting opinion in the appellate application when he stated,

"When the legislature has established a statutory right to review a decision that could affect the security of a person, it is a principle of fundamental justice that the state cannot unreasonably frustrate that right. When Parliament enacts a process for the review of decisions that deprive individuals of their liberty or security of the person, the state cannot, without reason, act to render that right of review illusory. The principle of fundamental justice, although derived from a statutory right of review,

1342002 CarswellOnt 83

1352002 CarswellOnt 364

${ }^{136}$ [2000] 2 A.C. 1 (Trinidad \& Tobago P.C.) 
can be applied, by analogy, to the process permitted by the covenant and the protocol. Individuals within Canada who face a deprivation of their right to life, liberty, or security of the person, have a right under s. 7 of the Charter, within reason, to have their petition reviewed by the Human Rights Committee free from any executive action that would render the review nugatory."137

Professional and civil society organisations therefore have a role to play in creating a favourable climate for treaty implementation and instigating implementation as seen in the Australian cases. The next chapters would elaborate on these roles.

${ }^{137}$ Supra note 134 , para. 86 


\section{HUMAN RIGHTS EDUCATION/ENLIGHTENEME NT AND THE ROLE OF PROFESSIONAL ORGANISATIONS}

This chapter is the beginning of the concluding sections of the thesis; it draws from the foregoing chapters and seeks to answer the question "what is the role...?" of the organisations under consideration. The preceding chapters have severally adumbrated the said 'role' and it is time to give some structure to the idea. The term 'civil society' encompasses a broad range of non-governmental actors and in that sense; there is no real demarcation between professional organisations and NGOs. However, the term has also been more narrowly defined. For example, the International Institute for Sustainable Development defined 'civil society' as “voluntary associations, organizations, movements and networks that live and work in the social space outside the state and the private sector." ${ }^{38}$ This definition clearly encompasses non-governmental organisations and to a certain degree leaves out professional organisations. It is therefore necessary to draw an imaginary line between the two although in the working of society, such a line does not always exist.

The other aspect that the reader must bear in mind is that the said role is "beyond international legal mechanisms" this fact is already apparent from the preceding chapters and would become more pronounced down the line. I chose to emphasise the 'non-legal' aspects of human rights treaty implementation because the legal mechanism can only be effective in a properly working society, in the human rights context, this can only happen, when certain aspects of the social and political fabrics of each country are changed to reflect treaty expectations. The non-legal aspects of implementation are as important as the legal mechanism, sometimes more so. According to $\mathrm{H}$. Steiner, the very notion of human rights protection needs to be reconsidered as to reach beyond conventional understanding of judicial or other enforcement of the law. He points out that since human rights violations implicate a state's political and social structures as well as culture, it is more productive to understand protection as extending to ways of changing the political and cultural understandings and assumptions that may underlie violation. ${ }^{139}$

\footnotetext{
${ }^{138}$ International Institute for Sustainable Development 'Word Watch Glossary' Developing Ideas Digest $<$ www.iisd.org/didigest/glossary.htm\#C $>$ visited on 14 October 2004

${ }^{139}$ See H. Steiner, Supra note 48, p.757
} 


\subsection{HUMAN RIGHTS EDUCATION GENERAL}

Education has already been identified as one of the more important methods of bringing about such change. It remains then for this thesis to outline the present and potential roles of the various professional organisations that form part of the general educational delivery system. These would include various teachers unions, academic and lecturers associations bar associations, medical practitioners associations and other professional associations that directly or indirectly play a part in education. NGOs also play a major role in human rights education; however, I have chosen to deal with the role of NGOs in the next chapter.

In addition to the paragraphs referred to in the last chapter, The World Conference on Human Rights, in paragraph 33 of the Vienna Declaration and Programme of Action ${ }^{140}$ stated that human rights education, training and public information were essential for the promotion and achievement of stable and harmonious relations among communities and for fostering mutual understanding, tolerance and peace. It recommended that States should strive to eradicate illiteracy and should direct education towards the full development of the human personality and the strengthening of respect for human rights and fundamental freedoms. It called on all States and institutions to include human rights, humanitarian law, democracy and rule of law as subjects in the curricula of all learning institutions in formal and non-formal settings.

Pursuant to this suggestion, The UN General Assembly, by resolution 49/184 of 23 December 1994 proclaimed the United Nations Decade for Human Rights Education, from 1 January 1995 to 31 December 2004. The General Assembly also welcomed the plan of action for the decade as contained in the Secretary General's report. This plan inter alia focuses on stimulating and supporting national and local activities and initiatives and is built upon the idea of a partnership between Governments, international organizations, non-governmental organizations, professional associations, individuals and large segments of civil society. ${ }^{141}$ Hence, the Vienna Declaration and the UN Decade for Human Rights Education envisaged a clear role in education for these professional organisations. This includes Partnership with governments to include human rights, humanitarian law, democracy and rule of law as subjects in the curricula of all learning institutions in formal and non-formal settings at national as well as local levels. Additionally, in line with the provisions of the UDHR and CESCR, these organisations have the role of ensuring that education results in

\footnotetext{
${ }^{140}$ Vienna Declaration and programme of Action 1993

${ }^{141}$ See generally United Nation Decade for Human Rights Education (1995 -2005), Office of the UN High Commissioner for Human Rights,

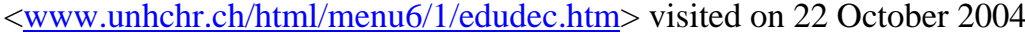


strengthened respect for human rights and fundamental freedoms as contained in the treaties and other instruments.

\subsection{PROFESSIONAL ORGANISATIONS AT PRIMARY AND SECONDARY EDUCATION LEVELS}

The major players at this level in terms of professional organisations are the various teachers unions and federations of such unions in most countries. Some countries have just one such union while others have several. More often, the teachers unions consist of mainly educators at the primary, secondary, teachers training, and technical college level. While university and tertiary institutions' lecturers belong to different unions, in a few cases the two categories are involved in the same union. This part would however be devoted to the unions of the former category. Examples of those include the Nigeria Union of Teachers, Australian Education Union, National Union of Teachers (England and Wales) and the Botswana Teachers' Union. These professional organisations generally operate as trade unions as well as professional associations. They generally focus on promoting and developing the teaching profession; provision of support and services to the members; the defence of public education and curriculum development.

Often these unions are very developed and experienced in their area of endeavour, very large and influential and in most countries, have a voice that cannot be easily ignored. They are usually organised with a central office and branch offices and centres throughout each country and in many cases maintain a presence at local or grass root levels. According to information on the National Union of Teachers website for example, "The NUT has a network of experienced and qualified staff, including a practising solicitor, in each of its offices throughout the English regions and in Wales to give immediate cover to teachers in trouble - legal and professional advice, guidance and support." 142

\subsubsection{Potential for Human Rights Promotion}

Already the potential of these unions to play a telling role in the promotion of human rights is evident. For one thing, there is not a single teachers union that is not already involved in human rights as in labour rights for members. In other words, the concept of human rights will not be new to any of them. For another thing, most teachers union are affiliates of Education

\footnotetext{
142 National Union of Teachers http://www.teachers.org.uk/story.php?id=2967 visited on 26 October 2004
} 
International, a global teachers' organisation that boasts of representing 29 million education personnel, 345 member organisations in 165 countries and territories. EI has stated her aims and objectives to include:

"To further the cause of organizations of teachers and education employees, to promote the status, interests, and welfare of their members, and to defend their trade union and professional rights;

to promote for all peoples and in all nations peace, democracy, social justice and equality; to promote the application of the Universal Declaration on Human Rights through the development of education and of collective strength of teachers and education employees;

to seek and maintain recognition of the trade union rights of workers in general and of teachers and education employees in particular; to promote the international labour standards, including freedom of association and the right to organize, to bargain collectively, and to undertake, industrial action, including strike action if necessary;

...to support and promote the professional freedoms of teachers and education employees and the right of their organizations to participate in the formulation and implementation of educational policies;

to promote the right to education for all persons in the world, without discrimination...

to foster a concept of education directed towards international understanding and good will, the safeguarding of peace and freedom, and respect for human dignity;

to combat all forms of racism and of bias or discrimination in education and society due to gender, marital status, sexual orientation, age, religion, political opinion, social or economic status or national or ethnic origin...,"143

These aims and objectives read almost like the constitution of an international human rights NGO and although EI is by its constitution precluded from interfering in the internal affairs of affiliate associations and unions, one would expect the same level of commitment to human rights promotion in the affiliate unions. Unfortunately, this is not frequently the case. Most of the Unions I studied, with a few exceptions, are more involved with the labour rights and other services to members than with the overt direction of education towards strengthening of respect for human rights in their pupils. To varying degrees, they also push for better study conditions in the different schools but the same bold commitment to human rights by EI is not always replicated in the aims and objectives available online. Nevertheless, the very structure of these unions, the experience gained over the years, the influence in society and the nature of the memberteachers' duties towards the students is a veritable recipe for promoting human rights treaty expectations. Also, regardless of available electronic information, I want to believe that many a school already provide for human rights in day to day teaching.

Starting with staff training, which most of the unions already provide for their members in some form, the principles of human rights education as contained in the UDHR, CECSCR and the UN Decade for Human Rights Education can be disseminated in a way that will positively impact the

143 Education International ‘Aims and Principles' < www.ei-ie.org/main/english/ > visited on 26 October 2004 
future generations that the present pupils represent. Armed with apposite human rights knowledge, these unions can, in partnership with governments, embark on curricula development to reflect human rights expectations. Where necessary and to the extent allowed by the law, the unions can incorporate human rights into the education system independently of formal state action especially where bureaucracy would impede the state or in states that are yet to become keen on human rights issues. Additionally, some unions are known to take formal stands on different aspects of national development and wellbeing, not unlike NGOs. In this way, teachers' unions can take a stand on human rights issues and can organise conferences and seminars or actively participate in such with the result of positive state policy.

\subsubsection{Current Achievements}

I admit that the above stipulations may run the risk of being considered farfetched or idealistic by some. Fortunately however, some unions have started heading in that direction. A notable example is the Australian Education Union, the union has a section of her website devoted to human rights. The section "aims to raise awareness of Human Rights and provide knowledge and skills for members to actively advocate for human rights in their work and personal lives, as well as visibly promote the human rights work the union is already undertaking." ${ }^{144}$ Further, in the same section, The AEU reveals a firm commitment to international involvement, achievement and protection of human rights standards as well as trade union rights. AEU also affirms that human and trade union rights are universal and indivisible. ${ }^{145}$

The union in partnership with Amnesty International has developed a Human Rights Training Manual, which was introduced in 2000 as part of AEU's contribution to the $50^{\text {th }}$ anniversary of the UDHR. The manual was designed to be used for trade union training; professional development of teachers; curriculum development for students by teachers and to be used by the community. AEU is also actively involved in and supports many community based human rights projects including 'Refugee Campaign', 'Say No to Racism', 'National Coalition Against Poverty'. The union also disseminates the Human Rights and Equal Opportunity Commission Education Resource: 'Bringing Them Home Education Module'. Produced for Australian schools, the resource is said to be a rich interactive human rights education module based on the stories, findings, recommendations and responses to the report of the National Inquiry into the Separation of Aboriginal and Torres Strait Islander Children from their Families.

AEU for its 2004 Anti-Poverty Week, asks a question: why not do something with your class or in your school? How very pertinent and precise a question, since all such union activities, to have treaty

\footnotetext{
${ }^{144}$ Australian Education Union 'Human Rights' < www.aeufederal.org.au/HR/index2.html> visited on 26 October 2004

${ }^{145}$ See generally Australian Education Union, Ibid
} 
implementation consequences, must get into the classroom. Precept upon precept, a foundation on all the human rights treaties and norms can be laid, more so as the pupils of today are the responsible citizens and state officials of tomorrow. Speaking of direct implementation of treaties, teaching human rights and fundamental freedoms in schools is in itself an implementation of Article 13 (1) of the International Covenant on Economic Social and Cultural Rights and Article 29 (1) (b) CRC.

\subsection{PROFESSIONAL ORGANISATIONS AT TERTIARY EDUCATION LEVEL}

The major professional organisations with the potential of affecting human rights education at the higher education level are the various lecturers unions and associations. Examples include the Academic Staff Union of Universities, Nigeria, National Tertiary Education Union, Australia and the Canadian Association of University Teachers. Much of the characteristics of the teachers unions discussed above are also true of these lecturers unions with a few important differences. These Unions are also large though not always as large as the teachers' union, influential; operate as trade unions and professional organisations and are highly organised. The National Tertiary Education Union of Australia for example is a democratic organization, with structures and processes designed to maximize membership participation and control. Members are organized through Workplace Branches each of which is part of a State or Territory Division, and in turn, part of the National Union. At Branch, Division, and National levels, there are officers and executive members elected by the membership to do the day-to-day work of the Union. There are also general meetings at each Branch, and broader elected councils at Division and National levels. The Union also employs staff at various levels to provide professional and administrative support to members. ${ }^{146}$

Because of the high level of specialization, institutional autonomy and academic independence at the higher education sector in most states, the lecturers unions do not play as central a role as do the teachers unions in curriculum development but are nonetheless a good starting point for strengthening general human rights based education the world over. In a number of states, particularly Commonwealth states, other professional organizations play a significant role in shaping particular courses in higher education. One category would be the various professional associations made up of practicing professionals. The other are quasi professional organizations, which are usually creations of statutes, created to regulate the particular profession and academic training and qualification into same, these are generally autonomous and usually consist in part of members appointed or elected from the professional associations.

\footnotetext{
${ }^{146}$ National Tertiary Education Union 'NTEU Organisation'

<www.nteu.org.au/about/organisation> visited on 3 November 2004
} 
The said associations usually have stakes in the training and development of future professionals. Examples of the former are associations of Engineers, Doctors, Architects, Nurses and lawyers, while examples of the latter are the various councils and institutes created in some cases by statute in consultation with the professionals to regulate the professions like the Institute of Chattered Accountants of Nigeria, Medical and Dental Council of Pakistan, Council of Legal Education, New Zealand. An Example from the medical profession in Nigeria would be helpful. The training of medical doctors and dentists in Nigeria is the sole responsibility of lecturers and consultants in the various medical colleges and faculties, these lecturers are members of the Academic Staff Union of Universities, Nigeria as well as members of the Nigerian Medical Association or the Nigerian Dental Association along with other medical doctors and dentists in Nigeria. The Medical and Dental Council of Nigeria, created by the Medical and Dental Practitioners' Act, in turn regulates the medical profession in Nigeria and the curricula of the medical schools. ${ }^{147}$ Of the twenty-two members of the council, eleven are to be nominated by the association. ${ }^{148}$ This example fairly represents the intricate relationship between professional organizations that play a role in higher education in most parts of the world and for wholesome human rights education in the higher institutions, all major players must be effectively mobilized and all definitely have a role to play.

\subsubsection{The Role of the Professional Associations and Regulatory Organisations}

Starting with the professional regulatory councils and institutes, where they are creations of statutes, they are usually empowered to make rules of professional conduct where applicable and in some states, empowered to develop the educational curricula of the schools. Accordingly, there is a much-defined role for these bodies. Rules of Professional conduct could be revised and brought to parity with human rights standards where this is not already so. Additionally, in those states where such bodies determine educational curricula, they have the possibility of introducing minimum human rights standards in each profession both in the areas particularly applicable to the profession and the incorporation of general respect for human rights. The Medical and Dental Council of Nigeria has recently made continuing professional development mandatory for all doctors for the purposes of license renewal, the council could actually have made related human rights standards part of this mandatory continuing medical education.

\footnotetext{
${ }^{147}$ CAP 221 Laws of the Federation of Nigeria (1990).

148 See generally Nigerian Medical Association 'About NMA'

$<$ www.nigeriannma.org/aboutus.htm> visited on 1 November 2004; Medical and Dental Council of Nigeria *Composition of MDCN' < www.mdcn.org/composition.htm $>$ visited on 3 November 2004
} 
The professional associations, aside from the lecturers also have a very important role to play regarding human rights; they are well placed to introduce profession-specific human rights norms into the profession as a whole as well as advocate for same to be made part of the training of future professionals. They are also well placed to consult with governments and where necessary campaign for the implementation of human rights treaties especially those directly linked to their profession. The vantage position of these professional associations or the potentials thereof vis $a$ vis the government is depicted by the Nigerian Medical Association, which has stated that

\begin{abstract}
"Although the Association is involved in many of the government's activities, it is consulted formally by the government only on an 'ad-hoc' basis. It is not consulted as 'of right' on health issues and has to press for its participation... The NMA is at present involved in influencing health policy formulation in an ad hoc manner. This is done by making unsolicited recommendations to government on various health issues and also by making inputs, whenever invited, to some of the national committee meetings on policy formulations”149
\end{abstract}

It becomes immediately apparent that the Association already has the necessary capacity to canvass for the implementation of international human rights in Nigeria. For instance, using the existing channels and connections, the association can advocate for the increased implementation of the standards contained in Article 11 CESCR on adequate standard of living, which has health consequences and Article 12 CESCR on highest attainable standard of physical and mental health. Since Nigeria is yet to fully incorporate the CESCR into her domestic law, the Association can join the other voices advocating for the incorporation on one hand and on the other hand, encourage the government to pursue such standards even without direct reference to the treaty. Additionally, the Association can also encourage the inclusion of these standards and other general and healthrelated human rights principles into already existing medical training programmes. The above example applies to all other professional associations.

\title{
4.3.2 The Role of Lecturers Unions
}

The need for the lecturers unions to contribute to human rights education and as a result to the implementation of the treaties cannot be overstated. In today's world, legislators, members of the executive and the judiciary are university graduates. Accordingly, today's lecturers have the opportunity of shaping the minds of tomorrow's policy makers, legislators and members of the bench in their various countries, making them more human rights oriented. If this task is handled with deserving vigour, in some years, it is foreseeable that those states that are still struggling with ratification of human rights treaties, incorporation of same and implementation would

${ }^{149}$ Nigerian Medical Association Ibid 
stand a better chance of leaving those struggles behind and those that are presently doing well would do even better.

The first step towards achieving this goal is for these unions to acquaint themselves with the extant human rights standards beyond the promotion of labour rights and other rights that form part of the usual workings of a trade union, where many unions have distinguished themselves. The aim at all times should be to build into the students a pervasive culture and world view based on human rights as a social paradigm anchored on international and municipal legal instruments. This aim can then be disseminated to the entire academia through seminars, conferences and the other channels of outreach between the union and the members. Curricula development is another issue altogether, higher education differs greatly from primary and secondary education here partly because of more emphasis on academic freedom at this level. According to the UNESCO Recommendation concerning the Status of Higher-Education Teaching Personnel, academic freedom is

\footnotetext{
"the right, without constriction by prescribed doctrine, to freedom of teaching and discussion, freedom in carrying out research and disseminating and publishing the results thereof, freedom to express freely their opinion about the institution or system in which they work, freedom from institutional censorship and freedom to participate in professional or representative academic bodies.”
}

As seen in Chapter 2 above, the Committee on Economic Social and Cultural Rights In its General Comment No.13, has outlined the content of academic freedom in similar terms and have indicated that the term is an implied part of Article 13 CESCR. This means that faculties and individual lecturers are the masters of their syllabi to a reasonable extent. The drawing of higher institution curricular should necessarily remain general. As a result, the principles of human rights as to be introduced in each field of study would have to be understood, accepted and embraced by each faculty and individual lecturers.

With the possible exception of governmental departments, the lecturers union are the best placed to play a role in realising this objective. In some states, faculty members are more likely to listen to peers. Other obstacles buttress the role of the lecturers unions, for example, it is foreseeable that some academics might reject the idea of human rights as having anything to do with their fields given that academics sometimes shun value-laden scholarship in the name of objectivity and scientific reasoning. Notwithstanding, as a minimum, the lecturers union should be able to encourage the introduction of human rights as a General Studies course or equivalent courses or programmes for freshmen in each university, this of course is in addition to other specialised human rights programmes that exist in many universities at undergraduate and postgraduate levels. To my knowledge, General Studies courses are compulsory for all students in Nigerian universities as well as in some universities in Cameroon and some other commonwealth countries. In Columbia University, USA, "The Undergraduate Human Rights Program at Columbia College serves 
Columbia College and the School of General Studies. Columbia College students may do a Special Concentration in Human Rights and General Studies students may do a Minor in Human Rights." 150 A human Rights general studies course is definitely a step in the right direction for all countries where this is not already so in some form and lecturers unions have the potential of making this happen. Progressively, the human rights dimension of all disciplines in higher education can in the same vain be vigorously researched and emphasised at the continued insistence of the unions.

\subsubsection{Who Will Teach The Teachers?}

Understandably, the constitutions and other terms of reference of the organisations and unions may not clearly include the above objectives. However, because of the treaties, declarations and other instruments discussed in chapter two above, the organisations should amend their constitutions where necessary to reflect the duties placed on them by contemporary international human rights standards. For this to happen and for the organisations to play the envisaged role willingly and effectively, they must first be sufficiently apprised of the extant human rights standards.

Such appraisal must aim to motivate the teaching of human rights with a commitment for action and the determination that all those who 'graduate' from any house of learning ought to move into the world with knowledge of human rights as a prevailing social concept underpinned by legal instruments. ${ }^{151}$ Lawyers and law teachers have a role to play regarding bringing other lecturers up to date with human rights standards. However, are the lawyers always ready to undertake the task? Usually when legal matters such as human rights are in issue, universities and lecturers unions turn to members of the law faculty. For example of the three members of the Committee of Inquiry appointed by the Canadian Association of University Teachers to investigate allegation of discrimination by a lecturer from the Physics Department, University of Toronto, two were law professors while the other is a physics professor. ${ }^{152}$ Although human rights are not the exclusive preserve of lawyers, it nonetheless is rooted in law and lawyers play a paramount role in its development and enforcement. Hence, regarding the necessary enlightenment and motivation of the academia and the training of future lawyers, the organisations that play a role in legal education deserve a little examination to identify their present and potential roles.

\footnotetext{
${ }^{150}$ See 'Human Rights Studies at Columbia'

$<$ www.columbia.edu/cu/humanrights/education/hr_studies.htm > 9 November 2004

${ }^{151}$ See Shulamith Koenig 'Human Rights Culture and NGOs' in S. Åkermark (Ed) Human

Rights Education Achievements and Challenges (Institute for Human Rights Åbo Akademi University, Turku/Åbo, 1998) p. 120

${ }^{152}$ CAUT.ACPPU 'News' $<$ www.caut.ca/en/news/comms/20030618chun.asp $>$ visited on 10 November 2004
} 


\subsection{LEGAL EDUCATION}

Lawyers are involved in the development of human rights, the implementation and enforcement of the treaties as incorporated into domestic law and indeed in facilitating access to international procedures. At one level, legal practitioners are the custodians of justice, human rights and fundamental freedoms. At another level, they have an unstated moral obligation to teach the principles of justice, human rights and fundamental freedoms to civil society. At yet a different level, qualified legal practitioners increasingly participate in the political workings of states. In some states significant numbers of members of the legislature are lawyers and many lawyers are actively vying for elected posts in the executive. Consequently, neither the importance of adequate human rights training nor the treaty-implementation dimensions of such training can be over emphasised.

Traditional legal training therefore should include not only the human rights safeguards in national laws but also more importantly the comparative and international aspects along with the decisions and views of international monitoring bodies and regional courts. ${ }^{153}$ With a sound knowledge of international standards, lawyers would be better prepared to lend their voice to any movement towards raising national human rights systems to international standards. Unfortunately, countries exist where traditional legal education still ignores this role. "The basic problem about international human rights law is not so much the applicability or inapplicability in national systems - the basic problem is how little is known around the world of its provisions!”154

\subsubsection{The Role of Professional Organisations in Legal Education}

Three different types of professional organisations are usually involved in legal education in most countries, including law teachers associations, regulatory bodies and bar associations/law societies. Examples of the first include the Irish Law Teachers Association, Australasian Law Teachers Association, Association of Law Teachers, UK and the Canadian Association of Law teachers. Examples of the second would be the Council of Legal education, Nigeria, Council of Legal Education, New Zealand; and the Caribbean Council of Legal Education. Examples of the third are the bar associations, bar councils and law societies that are invariably part of the legal profession in most countries.

\footnotetext{
${ }^{153}$ See generally Foreword by the International Bar Association 'Human Rights in the Administration of Justice: A Manual on Human Rights for Judges, Prosecutors and Lawyers' p. xxix

${ }^{154}$ Ibid
} 
Basic legal education in most countries starts with a university degree, followed by either a period of pupillage or by attendance in a bar school like the Nigerian law school, Law Development Centre, Uganda and the Japanese Legal Research and Training Institute. At the different levels of legal training, the roles of the different kinds of professional organisations are interrelated. The law faculties and lecturers draw up the curricula as sometimes approved by the councils of legal education and in most countries, the law teachers and members of the regulatory bodies are all qualified legal practitioners and members of the law societies or bar associations. As the umbrella organisations, these professional lawyers associations and societies are influential and can easily serve as the focal points for any move for improving human rights education in each country. Indeed, the role of the professional lawyers associations and law faculties are clearly spelt out in the Basic Principles on the Role of Lawyers. ${ }^{155}$ Article 9 exhorts for appropriate legal education that includes human rights and fundamental freedoms.

As a minimum, human rights law should be a compulsory part of every law faculty's curriculum including the international aspects of it. Where this is not so, both the law teachers associations and the professional lawyers associations can play a role in seeing that it becomes so. Further, the various bar schools and other pupillage programmes should endeavour to include the procedural rules of international human rights monitoring bodies and regional courts as compulsory parts of their curriculum. Although international human rights law increasingly forms part of the curricula of law schools and faculties around the world, it is only in some countries that it is a compulsory part of the basic law degree. ${ }^{156}$ In many other countries, human rights law courses are elective and this should change if there would be hope for pervasive and effective implementation of human rights treaties.

The regulatory bodies and accreditation boards should in all cases where a list of courses are required from university law graduates before admission to either bar schools or call to bar or articles, should ensure that international human rights law is part of that list of courses. In Nigeria for example, "the content of the course of study leading to the award of a law degree whether from a Nigerian or foreign University must be approved by the Council of Legal Education... The Council usually insists that the subjects taken must include Constitutional Law, Criminal Law, Law of Contract, Tort, Land Law, Equity \& Trust, Commercial Law, Law of Evidence." 157 According to this thesis, based on instruments such as the Declaration on Human Rights Defenders and the Basic Principles on the Role of Lawyers, this list of approved courses should be changed as soon as practicable to include international human rights law.

\footnotetext{
${ }^{155}$ See Section 3.2.2 above

${ }^{156}$ Examples includethe Chech Republic, Egypt, India, Romania and South Africa. See C. Heyns and F. Viljoen Supra note 3, pp. 489- 490

157 Nigeria-Law 'Legal Education’ < www.nigeria-law.org/Legal\%20Education.htm >1 November 2004
} 
The reason why there seems to be a lethargy regarding the inclusion of human rights law in law schools curricula may include that in some states, the knowledge of international human rights law and the treaties is limited to a new generation of lawyers. Professional lawyers associations should therefore contribute to the dissemination of human rights principles and knowledge to the older lawyers and law lecturers through seminars, conferences and the various continuing legal education programmes administered by professional lawyers associations in most countries. Sound human right training for lawyers is very important, as it would lead to both proactive and reactive implementation of the human rights treaties. Proactive regarding the increasing participation of lawyers in state policy formulation and legislation and reactive as in suits seeking redress through the judicature including international mechanisms for violations of human rights. 


\section{CIVIL SOCIETYINON- GOVERNMENTAL ORGANISATIONS PARTICIPATION}

As I have indicated at the beginning of the preceding chapter, the term 'civil society' can be given a broad or narrow meaning. In addition to the definition I used in the preceding chapter, it has also been defined as "a sphere of social interaction between economy and state, composed above all of the intimate (especially the family), the sphere of associations (especially voluntary associations), social movements, and forms of public communication." ${ }^{158}$ Civil society is hence often categorised as a third sector placed between the state and market economy to which much of the development of democratic society is attributed. ${ }^{159}$

The term describes a broad range of non-governmental actors including labour unions, consumer unions, religious, gender and issue oriented groups, public interest groups and associations of citizens and non-state institutions. Of all the groups that make up civil society a dominant subset, often used as a synonym for civil society, has emerged: non-governmental organisations sometimes also referred to as voluntary organisations. Although all groups that make up civil society are within the purview of this thesis and can indeed play the role described below, I have chosen to conveniently limit analysis and recommendations to human rights NGOs as representative of civil society for the discourse. Admittedly, NGOs have been in the limelight for some time and have benefited from extensive analysis and research. Consequently, this chapter would attempt a brief outline of the achievements of NGOs as human rights defenders and proceed to emphasise a few areas regarding the role of civil society in treaty implementation particularly areas that need to enjoy widespread utilisation.

\subsection{TRIBUTE TO CIVIL SOCIETY ORGANISATIONS}

Animal wan dash me human rights

\footnotetext{
${ }^{158}$ H. Steiner and P. Alston Supra note 44, p. 938, quoting Cohen and Arato, Civil Society and Political Theory (1992), ix.

${ }^{159}$ See E.g., Morten Kjaerum 'The Contributions of Voluntary Organisations to the Development of Democtratic Governance in A. Micou and B. Lindsnaes (Eds)' The Role of Voluntary Organisations in Emerging Democracies... (A Workshop Report) (Danish Centre for Human Rights/institute for International Education 1993) p. 13
} 
The words of late Fela Anikulapo Kuti, a renowned Nigerian musician in one of his music albums meaning: an animal wants to make a gift of human rights to me. An animal cannot make a gift of human rights to me. He was referring to the then Nigerian military government as the animal, which according to him has no moral standing to proclaim human rights for Nigerians. For one thing, human rights cannot be given; they are inalienable, for another thing, the government came to power in violation of the people's right to representative government. At least that is how I understood Fela at the time. Incidentally, this line in Fela's song provided me with one of my early instructions on the inalienability of human rights. At the time Fela and his fans represented a sector of civil society, other civil society organisations like the Civil liberties Organisation of Nigeria kept issues of democracy and human rights before the Nigerian public and indeed continually invited the scrutiny of the international community over the dictatorships that characterised the Nigerian politics for several years. As a result, they contributed to the overthrow of the different Nigerian dictatorships and the attendant human rights violations.

This Nigerian example illustrates perhaps the greatest contribution of civil society organisations to human rights, the generation and maintenance of public opinion on human rights issues. In Individual states, domestic NGOs act as checks on governments and urge the reconsideration of policies and programmes designed in disregard or in violation of human rights norms. They provide information and exert pressures that have sometimes led to foreign economic policies that consider human rights violations in other states. ${ }^{160}$ They have provided early warnings, acted as political watchdogs, played essential roles as educators and lobbyists, participated in human rights standard setting and today have become an indispensable part of the human rights system. At the international level, NGOs have been depended upon as independent sources of information particularly in the United Nations context; their 'shadow reporting' has enhanced the quality and reliability of the treaty monitoring system. A considerable proportion of initiatives to draft new international instruments, establish new procedures and identify particular states as violators are direct results of concerted NGO campaigns. ${ }^{161}$

\subsection{SELECTED HIGHLIGHTS ON THE ROLE OF NGOS}

The challenges of implementing international human rights law at the domestic level however remain evident in many states and violations continue to be everyday occurrences in some states. The degree of effective implementation differs from state to state, in the same way the degree of

\footnotetext{
${ }^{160}$ See generally, H. Steiner and P. Alston, Supra, note 44, p. 940.

161 Ibid.
} 
civil society participation and its effectiveness differs from state to state. Accordingly, this section would highlight specific roles that NGOs have played in different countries, which are worthy of emulation by NGOs from other states that are yet to embark on such roles.

\subsubsection{Participation in the Political Process}

The corollary of the international law guarantees discussed in section 3.3.2 above i.e. the provisions of sections 19, 21, 22 and 25 of the ICCPR read together with the relevant declarations particularly The Declaration on Human Rights Defenders, ${ }^{162}$ is the active participation of NGOs and related institutions in the political process of their various countries. In harnessing these guarantees, a key role of NGOs would be to develop expertise in articulating the views and desires of the citizens. These can in turn be transformed into political demands. ${ }^{163}$ Continuity in this would result in earning a place in the political process whether officially acknowledged or not. Success in this role depends on the NGO's ability to analyse and monitor human rights policies and compare same with international standards.

The traditional response to adverse policies or inaction is opposition and protest. While this response is highly fitting under dictatorial or other forms of repressive governments, there is need for a rethink and for NGOs to seek to forge new and different relationships with governments ${ }^{164}$ probably in addition to opposition and protests. NGOs can seek ways of obtaining consultative status in state parliaments or committees thereof analogous to the consultative status of NGOs in the UN Economic and Social Council. The art of lobbying and other forms of political pressure can be employed to this end. But when all else fails, the need to give effect to the treaties can be kept before the citizenry and where possible transformed into electoral issues until respect for human rights is achieved in the areas where it has been sought.

\subsubsection{Litigation, Public Interest Litigation and other Legal Processes}

The right to sue and be sued is one of the important attributes of legal personality, the status accorded most professional and civil society organisations in their countries. Litigation has therefore been a feature of civil society organisations particularly when their rights are directly violated. The Australian cases discussed at section 3.5 above illustrate the

\footnotetext{
${ }^{162}$ See section 3.2.1 above.

163 See also M. Kjaerum Supra note 159, p. 15.

${ }^{164}$ See also W. Carmichael 'The Particular Missions and Roles of VOs in Periods of Transition from Authoritarian to Democratic Policies' in A. Micou and B. Lindsnaes (Eds)' The Role of Voluntary Organisations in Emerging Democracies... (A Workshop Report) (Danish Centre for Human Rights/institute for International Education 1993) p. 19.
} 
importance of such litigation in the implementation of the treaties. To date, litigation takes the form of reactive application for redress of human rights violations and the principal role that NGOs have played is that of providing legal support and assistance. A good number of the cases are prosecuted on a pro bono basis and in this; the NGOs have frequently been the last hope of the powerless in the face violations. Wholesome treaty implementation would however call for more than reactive litigation.

NGOs may have to employ other initiatives in the area of litigation. For one thing, until the root-cause of violation is addressed and an adequate domestic climate created, continued violations would end up wearing out even the most committed organisations. For another, the agents of human rights violations are usually better funded and equipped in the litigation arena. Examples from different jurisdictions indicate that fresh initiatives that are worth trying include public interest litigations, class actions, precedent-hunting actions (for common law countries), petitions and general innovative advocacy.

Class actions suits would involve the combination of similar claims and causes of action of many victims of human rights violation. Such actions make for economy of scale and attract nationwide attention via the media, ensuring that the courts would not make a short shrift of a worthy case. Class actions have been extensively used by both NGOs and other public initiatives in the United States. In Leisner v. New York Tel. Co. ${ }^{165}$ 2,235 plaintiffs, all women employed in management level positions with the defendant, New York Telephone Company brought a class action pursuant to Title VII of the Civil Rights Act of 1964 , as amended ${ }^{166}$ for injunctive relief and damages. They alleged that the defendant, in violation of the statute, discriminates against women it employed in management level positions in its traffic departments throughout the state. Defendant's motion to dismiss the complaint on numerous grounds was denied and the court granted Plaintiffs' motions for a preliminary injunction and for class action certification even though only one plaintiff had received the notice of her right to sue at the date of commencement of the suit. Class actions are not permissible in every jurisdiction but where it is allowed civil society organisations should use it to facilitate the implementation of the treaties.

Public interest litigation involves court actions for the protection of "public interests" like fundamental human rights, environment and terrorism. ${ }^{167}$ Public interest litigation have been put to use in some countries including India, Uganda and Bangladesh. According to the report on the WHO Tobacco Free Initiative "Consultation on litigation and Public Inquiries as Public Health Tools”, 2001, Amman, Jordan, Advocates in Bangladesh have

\footnotetext{
165358 F. Supp. 359 D.C.N.Y., 1973

${ }^{166} 42$ USC $\S 2000 \mathrm{e}$

167 See also Helplinelaw 'Public Interest Litigation' < www.helplinelaw.com/docs/pub-ilitigation/index.php $>23$ November 2004
} 
fashioned creative "Public Interest Writ Litigation" in equity to advance tobacco control. ${ }^{168}$

"The case involved the use by British American Tobacco (BAT) of a
touring luxury yacht as a promotional vehicle for its cigarettes. Invoking
the right to life and liberty guaranteed by the Constitution of Bangladesh,
petitioners were able to establish that the BAT yacht constituted an
"advertisement" and that, more broadly, the use of any advertisement for
cigarettes without appropriate health warnings offended the constitutional
right to life". ${ }^{6}$.

Although the case was under review in the Bangladeshi highest court at the time of the Amman Consultation, the ruling sped up the formation of a national coalition of NGOs committed to tobacco control and the development of comprehensive national legislation. ${ }^{170}$ According to the same report, The Indian case of Shri Murli S. Deora, et al. v. Union of India, et al. brought out the almost unlimited power of public interest litigation. Commenced by writ petitions, the case took advantage of the right of citizens to petition the Supreme Court of India to enforce constitutionally guaranteed fundamental rights or to compel the government to do so. PIL via petitions bypass actions in law and are thereby cheaper and faster. The case was brought by the President of Mumbai Regional Congress Committee, Murli Deora against the Union of India and the major tobacco companies based on the fundamental rights of citizens to life, health and a clean environment.

\begin{abstract}
"The...petition argued that the Union of India had abrogated its duty to safeguard the public health, especially "the health of children of tender age," and had failed to act to control tobacco use. The petition requested that the Ministry of Health and Family Welfare be directed to develop a comprehensive national tobacco control policy, including the elimination of public smoking, adoption of stronger health warnings on cigarettes, meaningful enforcement of advertising restrictions, control of sales to children, and creation of a fund to compensate victims of smoking, to be funded by tobacco companies."171
\end{abstract}

The court granted these sweeping demands on 2 November 2002; it ordered the states of India to immediately order the banning of smoking in public places: hospitals, educational institutions, railways, public transport, courts, public offices, libraries and auditoriums. "At one stroke, the Court accomplished measures that had long been proposed and that were, at the time, under consideration before the Indian Parliament." 172 The foundation for PIL in India was perhaps laid in PUDR [People's Union for Democratic Rights] vs. Union of India ${ }^{173}$ where the Indian supreme court conceded that

\footnotetext{
${ }^{168}$ D. Blanke 'Towards Health with Justice Litigations and Public Inquiries as Tools of Tobacco Control' World Health Organisation 2002, p. 36; available online at $<$ www.who.int/tobacco/media/en/final_jordan_report.pdf > 23 November 2004 ${ }^{169}$ Ibid

${ }^{170} \mathrm{Ibid}$

${ }^{171}$ Ibid, p. 38

172 Ibid

${ }^{173}$ [1982 (2) S.C.C. 253]
} 
unusual measures were warranted to enable people the full realization of not merely their civil and political rights, but the enjoyment of economic, social, and cultural rights. ${ }^{174}$ The Court "recognized that a third party could directly petition it, whether through a letter or other means, and seek its intervention in a matter where another party's fundamental rights were being violated." 175

Public interest litigations have also been used by NGOs in Uganda in The Environmental Action Network, Ltd. v. Attorney General and National Environment Management Authority ${ }^{176}$ Like the Indian and Bangladeshi cases, this case petitions the Ugandan courts to protect the rights to life and clean and healthy environment pursuant to Articles 21 and 39 of the Constitution of Uganda.

Although the foregoing cases were prosecuted under the constitutions of the various countries, their treaty implementation potentials cannot be mistaken. Recently revised constitutions reflect treaty guarantees particularly the ICCPR and in some countries, ratified treaties form part of the constitution, an example is Kenya.

Starting with these petitions based on the constitutions, it is foreseeable that as the courts increasingly give heed to human rights pleas, incorporated and even non-incorporated treaties would soon become the subjects of successful petitions. NGOs are therefore encouraged to continue employing these tools in their treaty implementation role. In the area of litigation and other legal processes, the possibilities are unlimited, innovative advocacy should be the watchword, success would call for NGO advocates to think the unthinkable and frame human rights cases in new ways. Relief sought should go beyond redress for individual violations, and reach creative declaratory and injunctive relief, orders to implement as in the PIL cases and yes even large monetary recoveries that would inhibit future violations.

\subsubsection{Public Education and Information Provision}

The public is generally reliant on NGOs for information on human rights, in many states governmental information is taken with a pinch of salt as understandably, state sponsored information is bound to reflect the state's perspective on policies in question whether right or wrong. Accordingly, independent NGO information has become highly priced in both national and international processes. Human rights treaty bodies, foreign

\footnotetext{
${ }^{174}$ MANAS (UCLA) 'Public Interest Litigation'

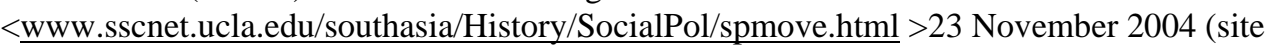
created by Vinay Lal Associate Professor of History, UCLA)

${ }^{175}$ Ibid

${ }^{176}$ Misc. Application No. 39 of 2001, High Court of Uganda. Taken from D. Blanke Supra note 168 , p. 42
} 
governments, international NGOs and intergovernmental organisations all routinely seek out NGO information and expertise in all human rights reporting in particular countries. NGOs therefore play an important role as to what human rights are understood to be in every state. Information made available to international organisations have resulted in international pressures of different kinds and is likely to continue to do so. Examples under the UN system include "shadow reporting" leading to adverse concluding observations and comments on country reports and the triggering of some of the procedures of Commission on Human Rights.

Public education by NGOs takes different forms including advocacy campaigns, which might be thematic or they may concentrate on specific human rights problems in a country, mobilising citizens and institutions to pressurise relevant authorities to address the issues by giving effect to the treaties. Officials in position to affect human rights implementation can also be educated during lobbying. Specific public educational campaigns and programmes take diverse forms including exhibitions, billboard messages, concerts, street performances, public debates, conferences, seminars, symposia and creative use of the media. Formal human rights training and education programmes have also been utilised particularly for members of the security forces, prisons and other government officials, the business community and even educators. Amnesty International through its country organisations and affiliates is a prime example of an NGO that has used all these methods. ${ }^{177}$

\subsubsection{Human Rights Training For Judges}

With the exception of initiatives from willing governments, intergovernmental organisations and projects sponsored by foreign agencies like the U4 Project in Ethiopia, sponsored by NORAD (Norway) ${ }^{178}$, NGOs are the other major facilitators of human rights training for judges. Traditional legal professional organisations like bar associations may not always be suited for this task mainly because the judges are of the bench while the lawyers are of the bar and deference flows from the bar to the bench.

In Nigeria for example, at wake of the infamous Sharia legislations and trials in the Nigerian states of Kano, Katsina, Bauchi and Jigawa states, it is The NGO, Legal Defence and Assistance Project (LEDAP), which is based in Lagos but has representation in northern Nigeria that became involved in a pilot training project for newly appointed sharia judges. Incidentally,

\footnotetext{
177 See C. Spanga 'Amnesty International's Human Rights Promotional and Educational Work' in S. Åkermark (Ed) Human Rights Education Achievements and Challenges (Institute for Human Rights Åbo Akademi University, Turku/Åbo, 1998) pp. 105-109.

${ }^{178}$ See U4 Project Information < www.u4.no/projects/project.cfm?id=619 $>$ visited on 1 December 2004.
} 
private companies funded the initial project and the request for funding from the state governments is yet to yield any results. ${ }^{179}$ Training in Human rights for judges is quite central to treaty implementation at the domestic level, hence while international, intergovernmental and foreign organisations have led the way, domestic initiatives must be added and NGOs have played a role in this respect and should continue doing so with increased vigour.

\subsubsection{Research and Generation of Policy Alternatives}

In States that have not displayed proficiency in adapting human rights policies to suit local conditions and in states engaged in transition to democracy. NGOs and other civil society organisations can play the role of generating policy options affecting the entire gamut of human rights public policy. The first step would be to engage in policy oriented research and bringing the findings to bear on the political and governmental processes. Another way is by developing pilot projects and urging their adoption of funding by governments on a lager scale. ${ }^{180}$ The Human Rights Training Project for Judges by Legal Defence and Assistance Project cited at 4.2.5 above is a clear example. Most of the judges in question were transferred to the Sharia Courts from the Area Courts that have limited jurisdiction compared to the Shari'a courts that have jurisdiction over capital offences. Most of them had no prior legal training (being judges of inferior courts) and no training in the new Sharia legislation and definitely none in human rights. ${ }^{181}$ The policy option of human rights training for the said judges that the government has been asked to fund, exemplifies this role. Open to NGOs are the various international networks by which experiences in other national settings that may be helpful in addressing similar needs at home could be identified and utilised.

${ }^{179}$ See Human Rights Watch 'VII Training of Judges' <www.hrw.org/reports/2004/nigeria0904/7.htm> visited on 1 December 2004.

${ }^{180}$ See generally W. Carmichael Supra Note 163, p. 20.

${ }^{181}$ Ibid. 


\section{REALISATION OF THE ROLE-CONCLUSION}

To a large extent the preceding chapters have been recommendational in form and as a result I would devote this concluding chapter to touching on some of the problems that could hinder the playing of the identified roles. In addition, I would address the issue of technical assistance but will limit analysis to the UN Technical Cooperation Programme in the Field of Human Rights although there are many other valuable forms of technical assistance. The technical cooperation programme, despite some of its shortcomings, is one of the solutions to civil society participation problems.

\subsection{OBSTACLES TO THE PERFORMANCE OF PROFESSIONAL AND CIVIL SOCIETY ORGANISATIONS}

Certain obstacles immediately come to mind upon careful consideration of the roles identified in the thesis as appertaining to the organisations discussed. Fortunately, none of those obstacles is insurmountable.

\subsubsection{Professional Organisations}

Regarding professional organisations and their role in human rights education, the first obstacle that comes to mind is the absence of awareness of the duty to participate in defending human rights. Consequently, most of the organisations I surveyed have no mention of human rights nor its advocacy and promotion in their constitutions and articles of association. It would be correct to assume that these professionals feel quite removed from the problems of human rights and its implementation in their jurisdiction. Sadly, this apathy extends to even lawyers associations. Indeed some teachers' unions seem to be more concerned with human rights than do some bar associations. Connected to the foregoing is the problem of knowledge of the relevant human rights standards.

Excepting the obvious expectation of motivation from the state governments, one solution would be to extend the reach of international human rights through international and regional professional organisations to which the national ones are affiliated. Examples would include Education International (EI), to which most teachers and lecturers unions are affiliated; and the International Bar Association (IBA), to which most national bar associations and law societies are affiliated. Incidentally, the IBA runs a human rights institute and EI by its constitution is committed to the promotion of human rights through education. However not all international 
professional organisations are already involved and one principal agency of motivation that should be able to contribute is the UN Technical Cooperation and Advisory Services in the Field of Human Rights.

\subsubsection{Civil Society Organisations}

Several problems face NGOs and other civil society organisations including that of credibility, since there are no standardised accreditation procedures for these organisation particularly NGOs; funding; fragmentation of efforts, where many NGOs pursue the same goals individually although concerted effort would be more effective. Beyond these, the problem I have chosen to address in this section is that of human rights education and advocacy training. NGOs play a role in human rights education. To ensure that this role is discharged with deserving effectiveness, they must themselves be well trained.

Effectiveness in this important role entails a clear understanding of human rights in theory and practice; the ability to inter alia, take a claim, assess its value, collect evidence and present same in a way that brings redress to the aggrieved. For this level of expertise and professionalism, training needs to be sought even when professionals such as lawyers are involved. "When professionals are engaged in human rights activities, it should not be assumed that they understand human rights theory or techniques. Simply because one is a lawyer does not necessary mean that he or she is trained in human rights." 182

Possible solutions to these problems would include, national coalitions of NGOs, this will not only solve the problem of fragmentation of effort but will ensure economy of scale for training programmes. Another possible solution would be the tapping into the international NGO network for materials and training programmes. S. Orlin has also suggested affiliation to an international human rights federation of organisation. Suggested advantages of this move include, better credibility as a result of the affiliation. "The benefit to the local group is it gains legitimacy of the parent body or federation and its proclamations now carry the force of an international group and not just the sentiments of a local organisation.”183 Additionally, national NGOs can receive training and technical support from the parent organisation or federation. ${ }^{184}$ Admittedly, not all NGOs can or should belong to a federation of NGOs and not all have the skill to tap into the existing network of NGOs worldwide. There is therefore a need for other forms of assistance. Once again one of the agencies that may have the

\footnotetext{
${ }^{182}$ T. Orlin ‘The Local Non-Governmental Organisation' in S. Åkermark (Ed) Human Rights Education Achievements and Challenges (Institute for Human Rights Åbo Akademi University, Turku/Åbo, 1998) p. 138

${ }^{183}$ Ibid, p.133

${ }^{184}$ Ibid
} 
resources facilities and potentials of achieving this is the UN Technical Cooperation and Advisory Services in the Field of Human Rights.

\subsection{UN TECHNICAL COOPERATION PROGRAMME}

As indicated at 3.2.5 above, The UN Technical Cooperation and Advisory Services has been in operation since 1955 but has been strengthened since the creation of the Office of the UN High Commissioner for Human Rights in 1994. At the creation of the United Nations Programme of Advisory Services in the Field of Human Rights by the General Assembly, ${ }^{185}$ the Secretary-General was authorised to make provisions for assistance in the field of human rights, including advisory services of experts, fellowships and scholarships, and seminars. The G A later increased the services under the programme to include regional and national human rights training courses. ${ }^{186}$ Today, the United Nations High Commissioner for Human Rights holds overall responsibility for the programme under the authority of the Secretary-General. ${ }^{187}$ By General Assembly resolution 48/141 of 20 December 1993, which spells out the High Commissioner's mandate, The OHCHR also coordinates relevant United Nations education and public information programmes in the field of human rights. ${ }^{188}$

\subsubsection{Content of the Programme}

The Technical Cooperation Programme adopts a comprehensive approach to human rights institution building. It views the following constituent elements for national efforts to secure the protection of human rights under the rule of law as fundamental:

(a) A strong Constitution, inter alia, incorporating internationally recognised human rights and fundamental freedoms

(b) A strong electoral system

(c) A strong legal framework, under the Constitution, which protects human rights and democracy and provides for effective redress in all key areas

(d) Strong national human rights institutions, including independent commissions on human rights and ombudsman offices, with structures and functions consistent with the United Nations Principles relating to the status

\footnotetext{
${ }^{185}$ General Assembly Resolution 926 (X) of 14 December 1955

${ }^{186}$ See UN Centre for Human Rights 'Advisory Services and Technical Cooperation in the Field of Human Rights’ Fact Sheet No.3 (Rev.1), (United Nations, Geneva, 1996) p.3

online at $<$ www.unhchr.ch/html/menu6/2/fs3.htm $>$ visited on 30 November 2004

${ }^{187}$ Ibid, p. 6

${ }^{188}$ General Assembly resolution 48/141 of 20 December 1993 para. 4 (d) and (e)
} 
of national institutions, as well as strong national human rights research and training institutes;

(e) A strong judiciary, which is independent, adequately empowered, adequately financed, adequately equipped, and adequately trained to uphold human rights in the administration of justice;

(f) A military which has ultimate allegiance to the Constitution and laws of the land, and to the democratic Government, and which is trained in and committed to the principles of human rights and humanitarian law attending legitimate military duties;

(g) Effective and accessible mechanisms for the resolution of conflicts between and among citizens and groups in society and State organs;

(h) Full incorporation into the international human rights system, including through ratification of or accession to international human rights treaties and training of government officials in implementing and reporting under those treaties;

(i) A society which is educated in its rights and responsibilities, including through national human rights curricula in primary, secondary and postsecondary education, and teachers trained in education for human rights and democracy;

(j) A strong civil society including adequately trained, equipped, financed and organized non-governmental human rights organizations, women's groups, labour unions and community organizations.

"Taken together, these essential elements provide for a legal and institutional framework which will best serve to entrench the rule of law in society and thereby secure the effective enjoyment of human rights and democracy." 189 Accordingly, the programme in partnership with other UN organs, governments and NGOs, offers support and assistance to states seeking to strengthen these elements. Assistance and support take the form of country programmes and targeted projects including advisory services of experts, training courses, workshops and seminars. Further supports include information and documentation projects, fellowships and some financial assistance.

For our purposes, (i) and (j) above on human rights education and strengthening of civil society are of particular relevance and they go to buttress the view that the programme is central to the realisation of the roles this thesis has attributed to professional and civil society organisations.

${ }^{189}$ UN Centre for Human Rights Supra note 186 pp. 7-11 


\subsubsection{Curriculum Development and Human Rights Education}

On Curriculum development and human rights education, the programme seeks to develop curricula for education on human rights for the primary, secondary and university levels, and for non-formal levels of education. The intention is to assist in the building of a human rights culture by encouraging the inclusion of human rights concepts in existing programmes; "assisting in the adaptation or modification of curricula where necessary; and providing instruction and assistance to those persons centrally involved in the human rights education process." ${ }^{190}$ To this end, the programme offers teacher training to both primary and secondary school teachers. It is however doubtful that the programme has fully identified the Unions and other professional organisations identified in this thesis as instrumental to the realisation of the education objective.

However, as would be seen below, other efforts of the programme could influence these organisations and as stated in the Fact Sheet, Courses can also be constructed to accommodate other groups in a position to promote human rights education and sensitize others in this field. ${ }^{191}$ Present beneficiaries include teacher trainers, directors of schools or teacherresource centres, and inspectors and teachers within the ministry concerned with curriculum development and education. The programme nonetheless cooperates with universities ${ }^{192}$ and labour unions form part of the targeted beneficiaries of civil society strengthening. My recommendation would be emphasis on the human rights education roles of the labour unions particularly the category identified in this thesis.

\subsubsection{Support to NGOs and Civil Society}

Municipal and international human rights NGOs are key actors in the Technical Cooperation Programme. They both assist in the delivery of assistance, and benefit as recipients of it. Thus, in furthering the programme's goal of strengthening civil society, the programme is increasingly being called upon by Governments and others to assist national NGOs, in the context of its country activities, by soliciting their input, including them as invitees in seminars and training courses, and supporting appropriate projects developed by them. ${ }^{193}$ Hence, the catalytic role of the programme regarding civil society participation in treaty implementation is already underway. If only the programme's expectations are similar to those of

\footnotetext{
${ }^{190}$ Ibid, p. 16

191 Ibid

${ }^{192}$ See Ibid, p. 20

${ }^{193}$ Ibid, p. 17
} 


\subsubsection{At the Request of States!}

By General Assembly Resolution 926 (X) of 14 December 1955, the Secretary General was to make provision at the request of governments for advisory services; fellowships and scholarships; and seminars. These were to be done subject to the Direction of the Economic and Social Council, with the cooperation of the specialised agencies where appropriate and without duplication of their existing activities. ${ }^{194}$ The same condition of providing services and assistance at the request of the state concerned was repeated in General Assembly resolution 48/141 of 20 December $1993^{195}$ on the functions and mandate of the UN High Commissioner for Human Rights relating to the technical cooperation programme. Accordingly, technical cooperation projects and advisory services have been undertaken from inception on this premise. In my opinion, this is one of the major limitations on the effect of the technical cooperation programme since states who are not yet keen on human rights are very unlikely to make such requests despite the fact that they are the ones most in need of the programme. Perhaps this is a prime example of the limitations in the reach of the international human rights system into the domestic sphere as occasioned by state sovereignty.

Fortunately, in practice, aspects of the programme obviate the precondition of request by states. These are the aspects that hold the real hope of assistance to civil society in states that are yet to become keen on human rights standards implementation. These aspects include the following:

\subsubsection{Training Materials}

The High Commissioner is the co-ordinator of the United Nations Decade for Human Rights Education 1995-2004 and as part of the decade; the programme has continued to develop its series of training manuals and handbooks, for use by both instructors and participants. Notable for our purposes among the manuals and handbooks is The OHCHR Professional Training Series, designed primarily to provide support to the training activities carried out by the Office and also to assist other organizations involved in human rights education for professional groups. Other materials include training packages and manuals for peacekeepers, judges and lawyers, prison officials, primary and secondary schoolteachers, journalists, and national and local non-governmental organizations.

These coupled with the OHCHR database on human rights education searchable in English ${ }^{196}$ may be weak regarding direct response to the treaties implementation challenge. However, any motivated organisation determined to cause change would find them invaluable and of course, there is no need for prior request from states for these to be employed. For

\footnotetext{
${ }^{194}$ See Para. 2 (a) GA Resolution 926 (X) of 14 December 1955

195 See Para. 4 (d) and (e) GA Resolution 48/141 of 20 December 1993

$196<$ www.unhchr.ch/hredu.nsf >
} 
instance, the manual "Human Rights in the Administration of Justice: A manual on Human Rights for Judges, prosecutors and lawyers", produced in cooperation with International Bar Association is currently enjoying wide usage and is severally published in many institutions' websites.

\subsubsection{Regional Activities}

Another aspect of the programme that can influence professional and civil society organisations even in states that have not made the envisaged request is the aspect of regional activities of the programme. Examples include the activities of the Regional Programme Office for Southern Africa, which focuses on capacity building for civil society organisations, academic institutions, etc; ${ }^{197}$ And the regional project "Strengthening the Capacities of the Civil Society for a better Promotion of Human Rights in the Arab Region" being run in cooperation with the Arab Institute of Human Rights (AIHR). The project has the objectives of assisting the AIHR in reinforcing the capacities and professionalism of Arab NGOs that promote and protect human rights by training their staff. It also provides training to NGO human rights trainers. OHCHR provides the AIHR with financial support which helps sustain the institute's recently adopted working approach that emphasizes research, documentation, systematic activity planning and management. ${ }^{198}$

The Project with AIHR comes closest to circumventing prior state request for technical assistance particularly relating to civil society. The Arab Institute of Human Rights is a Tunis based independent Arab NGO founded in 1989. It aims to raise awareness on civil, political, cultural, social and economic human rights. It also aims to disseminate and promote human rights education through seminars, workshops, research, surveys on women's rights, child rights, etc. Above all, it operates in twenty Arab Countries, ${ }^{199}$ some of which are unlikely to request the services of the technical cooperation programme but are nonetheless affected by the present cooperation between the programme and AIHR. It is indeed desirable that states request the assistance but where this is yet to happen, The OHCHR is to be encouraged to continue with such cooperation efforts until the overall objective of the human rights movement is reached.

\footnotetext{
${ }^{197}$ See OHCHR ”Africa” < www.unhchr.ch/html/menu2/techafrica.htm > visited on 5 December 2004

198 See OHCHR ”Arab Region” < www.unhchr.ch/html/menu2/techarab.htm > visited on 5 December 2004

199 Algeria, Bahrain, Egypt, Iraq, Jordan, Lebanon, Libyan Arab Jamahiriya, Morocco, Palestinian Occupied Territory, Qatar, Saudi Arabia, Sudan, Syrian Arab Republic, Tunisia, United Arab Emirates, and Yemen. See CRIN “Arab Institute for Human Rights”

$<$ www.crin.org/organisations/viewOrg.asp?ID=47 > visited on 5 December 2004
} 


\subsection{CREATING CIVIL SOCIETY}

Thus far, a few of the problems that face professional and civil society organisations have been touched. However, there remains the question of the situation in states where the civil society sector is largely undeveloped. The need for professional and civil society organisations to participate in implementation is most acute in new or emerging democracies. Unfortunately, a number of these new democracies are also the states in which civil society is all too rudimentary and needs to be formed from the scratch in some cases. What then should be done?

In my opinion, real answers to the above question can only come from the people concerned, a healthy civil society can be encouraged and assisted from outside a state but is difficult if not impossible to build from outside. The solutions suggested above to professional and civil society organisations' problems are also valid for creating civil society from the scratch, particularly technical assistance. However, those solutions should remain catalytic and long term in outlook, the need for active civil society cannot justify artificial importation of methods. Teaching on equality before the law and non-discrimination, Professor Gudmundur Alfredsson once said that sometimes there is a duty on those being discriminated against, to react in protest to the violation of human rights before external assistance would be forthcoming. He cited the example of the Roma people in Europe and opined that until they made some noise about their plight, few people paid attention to their problem. ${ }^{200}$ The same principle is applicable in my opinion to the formation of human rights NGOs for example.

The will to advocate for human rights must first exist followed by the first advocacy steps however stunted. It would not be practicable for this thesis to fully examine the myriad factors that combine to birth civil society but one of the factors would be information and its availability. When society begins to react to non-implementation of the treaties probably due to available information and when groups begin to form in response, then the highly necessary technical assistance would be appropriate to strengthen and streamline advocacy efforts. In her concluding observations on the role of international organisations in strengthening human rights performances in the Baltic Sea, I. Ziemele stated, "only when there is a clear understanding of the existence of a problem by these societies themselves can one begin to search for solutions through the assistance of different international forums." ${ }^{201}$ The same is true of the process of civil society formation.

All such solutions in the nature of technical assistance should be preceded by in-depth research to find out how best to adapt human rights standards to local conditions since "without the understanding of their reasons and aims

\footnotetext{
${ }^{200}$ Raoul Wallenberg Institute/Faculty of Law, Lund University, Sweden (Lecture on Human Rights and Humanitarian Law Course, Fall 2003)

${ }^{201}$ Ineta Ziemele 'The Role of International Organisations in Strengthening Human Rights Performances in The Baltic Sea’ 43 German Yearbook of International Law (2000) p. 35
} 
by the recipients and, of course, without the ability to adopt them to local circumstances cannot achieve all the expected results." ${ }^{202}$ Perhaps it is time for the various international organisations and programmes that have contributed to the promotion of human rights to shift focus to researching ways of birthing civil society. One thing though is sure, regardless of how presently removed a society is from international human rights standards, sooner or later different factors would culminate into a call for human rights protection not least because human rights are inherent in man. Whenever and wherever this happens, I am hopeful that the suggestions of my thesis would prove useful. Tyranny, dictatorships and rights violation may suppress people for a season but history indicates that these too would pass.

\subsubsection{Rethinking Technical Cooperation Programmes}

Besides the UN Technical Cooperation Programme, professional and civil society organisations do receive diverse forms of technical assistance from different organisations including foreign governments, international, regional and intergovernmental organisations as well as international NGOs. These assistance programmes are indeed invaluable to human rights promotion and would remain so for formulation of healthy civil society in emerging democracies. However, for the reasons given above, technical assistance programmes would profit from some re-examination to solve the problem of incomplete or partial realisation of intended results.

In South West Cameroon in late 2003, a technical assistance programme administered as the South West Technical Group sought to encourage civil society involvement in HIV/AIDS campaign by financial assistance. This led to the formation of many bogus associations with the primary aim of claiming the proffered funds. Such provision of funds would probably have been effective in established democracies but did not work so well in Cameroon. Fortunately, the weak efforts executed as justification for received funds resulted in some measure of sensitisation, which has been partially helpful given the nature of the HIV/AIDS problem.

Sadly, similar programmes exist in the human rights field that reveal a direct importation of methods and ideas, which do not countenance the peculiarities of domestic situations. For instance, I. Ziemele remarked that it seems that in providing technical assistance and advisory services (and some substantial assistance), western democracies found it difficult to fully assess how deeply the communist regimes had affected the societies of the Baltic Sea region. ${ }^{203}$ Truly, it may be better to allow a few years for the development of civil society methods than to automatically adopt methods suggested by international experts without a real understanding of the

${ }^{202}$ Ibid
${ }^{203}$ Ibid 
methods. ${ }^{204}$ Consequently, I believe that these programmes would bear more fruit if each new programme starts with society-based research and seeks out innovative roles including those identified in this discourse.

\subsection{CONCLUDING REMARKS}

The notion that treaty implementation is exclusively the responsibility of states is no longer entirely defensible in the field of human rights. The crux of my thesis has been that professional and civil society organisations also have a role to play. The term 'role' implies responsibility. Using duty as a synonym for the word, Cambridge Advanced Learners Dictionary defines it as "the position or purpose that someone or something has in a situation, organization, society or relationship." ${ }^{205}$ Borrowing the language of this definition, I am persuaded that this thesis has at least attempted to show that professional and civil society organisations occupy an important position in the entire scheme of human rights implementation both in law and fact.

Some of the identified roles could directly result in treaty implementation; an example would be municipal litigation and other legal processes by civil society organisations. Other roles bear indirectly on the treaty implementation aim, examples would include lobbying and the influencing of public opinion by civil society organisation. Yet other roles result in a hybrid of direct and indirect implementation of human rights treaties, human rights education efforts of professional organisations exemplify this hybrid role since education in human rights leads to a culture that will end up facilitating treaty implementation. At the same time taking human rights into the classroom is a direct implementation of some of the provisions of the CESCR and CRC on the objectives and content of education. Nevertheless, all the identified roles are equally important and I am looking forward to the day when the activities that constitute the roles would become uniformly commonplace in all countries.

As indicated in the thesis, several problems affect these organisations and in some states civil society is undeveloped. However, as also noted, these problems are all surmountable and they do not detract from the fact that while national courts are blowing muted trumpets on account of nonincorporation of the human rights treaties, civil society organisation can and have taken governments to task by bringing them before the court of public opinion and by so doing, eliciting positive response. That while notions of independence and state sovereignty hinders treaty-monitoring bodies, these organisations could charge ahead and demand implementation, resting in all the advantages that being nationals of the same states can provide. That while political and other considerations result in subdued rhetoric instead of

\footnotetext{
${ }^{204}$ See I. Ziemele Ibid

${ }^{205}$ Cambridge Advanced Learners Dictionary http://dictionary.cambridge.org/define.asp?key=68410\&dict=CALD, visited on 15 December 2004
} 
inter-state complaints, these organisations, through the facilities of global networks, access to intergovernmental organisations and the help of international NGOs, could present the same complaints to the world and elicit the possible responses that the 'shame factor' can give. Accordingly, my recommendation is that all bodies that render technical or financial aid to such organisations should direct research to these roles and point the organisations they sponsor to the same direction. As a final caveat, I would like to clarify that the position taken by the thesis does not detract from the fact that primary responsibility for human rights treaties implementation continues to rest on state parties. 


\section{Bibliography}

\section{BOOKS}

Alfredsson G. and Eide A. (Eds.)

The Universal Declaration of Human Rights (Kluwer Law International, The Hague, 1999)

Eide A. and Crause C. (Eds.)

Economic Social and Cultural

Rights A Textbook (Kluwer Law International, The Hague, 2001)

Evans M.

International Law (ed.) (Oxford University Press, Oxford, 2003)

Heyns C. and Viljoen F.

The Impact of the United Nations Human Rights Treaties on the Domestic Level (Kluwer Law International, The Hague, 2002)

Joseph S. et al.

The International Covenant on Civil and Political Rights Cases, Materials, and Commentary (Oxford University Press, New York, 2000)

Kalshoven F. and Zegveld L.

Constraints on the Waging of War an Introduction to International Humanitarian Law (ICRC, Geneva, 2001)

Matsheza P. and Zulu L.

Melander G. et al.

Human Rights Enforcement and Implementation Mechanisms (Human Rights Trust of Southern Africa, Harare, 2001)

The Raoul Wallenberg Institute Compilation of Human Rights Instruments (Martinus Nijhoff, Leiden/Boston, 2004)

McGoldrick D.

The Human Rights Committee Its Role in the Development of the International Covenant on Civil and Political Rights (Oxford University Press, New York, 1994) 
Micou A. and Lindsnaes B. (Eds)

Schechter M. (ed.)

Shaw M.

Steiner H. and Alston P.

Åkermark S. (Ed)
The Role of Voluntary

Organisations in Emerging

Democracies... (A Workshop

Report) (Danish Centre for Human

Rights/institute for International

Education 1993)

United Nations-sponsored world conferences: Focus on impact and follow-up (United Nations

University Press, Tokyo, 2001)

International Law (Cambridge University Press, Cambridge, 2003)

International Human Rights in Context Law, Politics, Morals (Oxford University Press, Oxford, 2000)

Human Rights Education Achievements and Challenges (Institute for Human Rights Åbo Akademi University, Turku/Åbo, 1998) pp. 105-109.

'The Impact of the United Nations Human Rights Treaties on the Domestic Level', 23 Human Rights Quarterly (2001)

Ziemele I.
'The Role of International

Organisations in Strengthening Human Rights Performances in The Baltic Sea' 43 German Yearbook of International Law (2000)

\section{INTERNET ARTICLES AND RESOURCES}

Australian Education Union 'Human Rights' $<$ www.aeufederal.org.au/HR/index2.html > visited on 26 October 2004

Blanke D. 'Towards Health with Justice Litigations and Public Inquiries as Tools of Tobacco Control' World Health Organisation 2002, p. 36; available online at $<$ www.who.int/tobacco/media/en/final_jordan_report.pdf $>23$ November 2004 
Cambridge Advanced Learners Dictionary

http://dictionary.cambridge.org/define.asp?key=68410\&dict=CALD

CAUT.ACPPU 'News'< www.caut.ca/en/news/comms/20030618chun.asp $>$ visited on 10 November 2004

CRIN “Arab Institute for Human Rights”

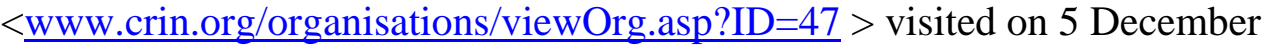
2004

Education International 'Aims and Principles' < www.ei-

ie.org/main/english/ > visited on 26 October 2004

Helplinelaw 'Public Interest Litigation' < www.helplinelaw.com/docs/pubi-litigation/index.php $>23$ November 2004

'Human Rights Studies at Columbia'

$<$ www.columbia.edu/cu/humanrights/education/hr_studies.htm $>9$

November 2004

Human Rights Watch 'VII Training of Judges'

$<$ www.hrw.org/reports/2004/nigeria0904/7.htm> visited on 1 December 2004.

International Institute for Sustainable Development 'Word Watch Glossary'

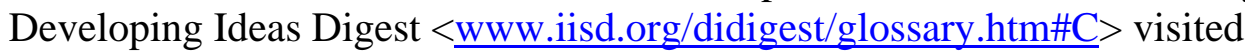
on 14 October 2004

MANAS (UCLA) 'Public Interest Litigation'

$<$ www.sscnet.ucla.edu/southasia/History/SocialPol/spmove.html $>23$

November 2004 (site created by Vinay Lal Associate Professor of History, UCLA)

Medical and Dental Council of Nigeria 'Composition of MDCN'

<www.mdcn.org/composition.htm> visited on 3 November 2004

National Tertiary Education Union 'NTEU Organisation'

$<$ www.nteu.org.au/about/organisation> visited on 3 November 2004

National Union of Teachers http://www.teachers.org.uk/story.php?id=2967 visited on 26 October 2004

Nigeria-Law 'Legal Education' $<$ www.nigeria-

law.org/Legal\%20Education.htm $>1$ November 2004

Nigerian Medical Association 'About NMA'

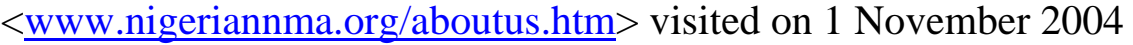


OHCHR “Africa” < www.unhchr.ch/html/menu2/techafrica.htm $>$ visited on 5 December 2004

OHCHR ”Arab Region” < www.unhchr.ch/html/menu2/techarab.htm > visited on 5 December 2004

OHCHR 'Declaration on Human Rights Defenders'

$<$ www.ohchr.org/english/issues/defenders/declaration.htm> visited on 29 July 2004

OHCHR 'Human Rights in the Administration of Justice: A Manual on Human Rights for Judges, Prosecutors and Lawyers’

OHCHR 'Technical Cooperation'

$<$ www.unhchr.ch/html/menu2/techcoop.htm>

U4 Project Information < www.u4.no/projects/project.cfm?id=619 $>$ visited on 1 December 2004.

UN Centre for Human Rights 'Advisory Services and Technical

Cooperation in the Field of Human Rights' Fact Sheet No.3 (Rev.1),

(United Nations, Geneva, 1996) p.3 online at $<$

www.unhchr.ch/html/menu6/2/fs3.htm> visited on 30 November 2004

United Nation Decade for Human Rights Education (1995 -2005), Office of the UN High Commissioner for Human Rights,

<www.unhchr.ch/html/menu6/1/edudec.htm> visited on 22 October 2004

Westlaw International http://www.westlawinternational.com/ 


\section{Table of Cases}

$<$ Case $>$

$<$ Case $>$ Ahani v.R 2002

CarswellOnt 83

Australian Education Union v Human Rights and Equal Opportunity Commission and Another, 80 FCR 46

Case Concerning Military and Paramilitary Activities in and Against Nicaragua (Nicaragua v. United States of America) 1986 I.C.J. 14

Cyprus V. Turkey (2002) 35 E.H.R.R. 30 ECHR

Interpretation of Peace Treaties with Bulgaria, Hungary and Romania1950 I.C.J. 65 Para. 105

Koowarta v. Bjelke-Petersen and Others153 C.L.R. 168

Leisner v. New York Tel. Co. 358 F. Supp. 359 D.C.N.Y., 1973

PUDR [People's Union for Democratic Rights] vs. Union of India 1982 (2) S.C.C. 253]

Shri Murli S. Deora, et al. v. Union of India, et al

The Environmental Action Network, Ltd. v. Attorney General and National Environment Management Authority Misc. Application No. 39 of 2001, High Court of Uganda

Thomas v. Baptiste. [2000] 2 A.C. 1 (Trinidad \& Tobago P.C.)

Transport Equipment and another v. D, P. Valambhia, Civil Application No. 19 of 1993 Court of Appeal, Dar es salaam. 


\section{Table of International Instruments, Resolutions, Concluding Observsations, General Comments and Statutes}

TREATIES

Charter of the United Nations 1945

Convention Against Torture and Other Cruel, Inhuman or Degrading Treatment or Punishment (CAT) (1984)

Convention on the Elimination of All Forms of Discrimination Against Women (CEDAW) (1979);

Convention on the Elimination of all Forms of Racial Discrimination (CERD) (1965);

Convention on the Rights of the Child (CRC) (1989)

European Convention for the Protection of Human Rights and Fundamental Freedoms 1950

International Covenant on Civil and Political Rights (ICCPR) (1966) and its first Optional Protocol (OP1)

International Covenant on Economic, Social and Cultural Rights (CESCR) (1966)

\section{RESOLUTIONS AND DECLARATIONS}

Basic Principles on the Role of Lawyers, Eighth United Nations Congress on the Prevention of Crime and the Treatment of Offenders, Havana, 27 August to 7 September 1990, U.N. Doc. A/CONF.144/28/Rev.1 at 118 (1990)

Declaration on the Right and Responsibility of Individuals, Groups and Organs of Society to Promote and Protect Universally Recognized Human Rights and Fundamental Freedoms, 1998

General Assembly Resolution 48/141 of 20 December 1993

General Assembly Resolution 926 (X) of 14 December 1955 
The Universal Declaration of Human Rights, General Assembly Resolution 217A (III) of 10 December 1948

Vienna Declaration and Programme of Action, World Conference on Human Rights, Vienna, 14-25 June 1993, A/CONF. 157/23

\section{GENERAL COMMENTS}

Committee on Economic, Social and Cultural Rights 'General Comment No. 13’, E/C.12/1999/10, 08/12/1999

Human Rights Committee, General Comment No. 10: Freedom of expression (Art. 19): 29/06/83

Human Rights Committee, General Comment No. 25, The right to participate in public affairs, voting rights and the right of equal access to public service (Art. 25): 12/07/96, CCPR/C/21/Rev.1/Add.7

\section{CONCLUDING OBSERVATIONS}

Concluding Observations of the Human Rights Committee: Australia, A/55/40, 24/07/2000, paras.498-528

Concluding Observations of the Human Rights Committee: Brazil, CCPR/C/79/Add.66; A/51/40, 24/07/96, paras.306-338

Concluding observations of the Human Rights Committee: Canada CCPR/C/79/Add.105, 07/04/99,

Concluding observations of the Human Rights Committee: Colombia, CCPR/CO/80/COL, 26/05/2004

\section{STATUTES}

CAP 221 Laws of the Federation of Nigeria (1990)

Constitution of the Federal Republic of Nigeria (1999)

\section{ENDNOTES TO THE INTRODUCTION}

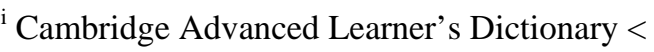
dictionary.cambridge.org/define.asp?key=39421\&dict=CALD $>$ visited on 14 December 2004
} 
${ }^{\text {ii } I b i d}$

iii See e.g., Article 2 (1) \& (2) ICCPR

iv See e.g., Article 2 (3) ICCPR

${ }^{\mathrm{v}}$ H. Steiner and P. Alston Supra note 44, p. 938, quoting Cohen and Arato, Civil Society and Political Theory (1992), ix.

${ }^{v i}$ See E.g., Morten Kjaerum 'The Contributions of Voluntary Organisations to the

Development of Democtratic Governance in A. Micou and B. Lindsnaes (Eds)' The Role of Voluntary Organisations in Emerging Democracies... (A Workshop Report) (Danish

Centre for Human Rights/institute for International Education 1993) p. 13

vii Cambridge Advanced learner's Dictionary Supra note 1

viii (Kluwer Law International, The Hague, 2002) also available in C. Heyns and F. Viljoen 'The Impact of the United Nations Human Rights Treaties on the Domestic Level', 23

Human Rights Quarterly (2001)

$<$ muse.jhu.edu/journals/human_rights_quarterly/v023/23.3heyns.html>, visited on 30 June 2004.

${ }^{\text {ix }}$ World Health Organisation 2002, p. 36; available online at

$<$ www.who.int/tobacco/media/en/final_jordan_report.pdf $>23$ November 2004 